\title{
13. FOSSIL PRESERVATION AND DIAGENESIS OF PELAGIC CARBONATES FROM THE MAGELLAN RISE, CENTRAL NORTH PACIFIC OCEAN ${ }^{1}$
}

\author{
Seymour O. Schlanger, University of California, Riverside, California \\ Robert G. Douglas, Case Western Reserve University, Cleveland, Ohio \\ Yves Lancelot, Lamont-Doherty Geological Observatory, Palisades, N.Y. \\ T. C. Moore, Jr., Oregon State University, Corvallis, Oregon \\ and \\ Peter H. Roth, Scripps Institution of Oceanography, La Jolla, California
}

\section{INTRODUCTION}

The Magellan Rise is a large plateau located in the central Pacific, just north of the equator $\left(07^{\circ} 04.1^{\prime} \mathrm{N}\right.$, $\left.176^{\circ} 49.5^{\prime} \mathrm{W}\right)$ in a water depth of 3176 meters. Site 167 is located near the crest of the rise where a hole was drilled to the basaltic basement. The sedimentary section drilled is a nearly continuous sequence of pelagic carbonates, ranging from Quaternary ooze at the top to Tithonian-Berriasian limestone at the bottom. The section is 1172 meters thick, and most of it was continuously cored (Figure 1). Downhole, there is a gradual change in lithology, so that a complete spectrum of carbonate rocks from oozes to chalks to limestones was recovered. The sedimentary sequence on the Magellan Rise, because of the fairly unique combination of location, depth, thickness, and lithologies, provided a rare opportunity to study the changes in fossil preservation and diagenesis of a pelagic carbonate sequence.

We have approached this study in two ways. First, we have combined the observational data collected during routine shipboard operations with subsequent thin-section, scanning electron microscopy (SEM) and paleontological studies in order to describe the progressive changes, with depth, in fossil preservation, development of cement and "micritic" cement, and compaction of the sediments. Second, we have used the observational data as a basis for a general model of diagenesis in deep-sea, pelagic carbonates.

Our data suggest that the main diagenetic processes in pelagic sediments involve a selective alteration of the original skeletal components which form the sediments. At Site 167 these processes involve the dissolution and destruction of foraminifera, and to a lesser degree, nannofossils, and the concomitant buildup of calcite overgrowths and the precipitation of interstitial cement.

Diagenesis begins when the original skeletal material sinks from the upper layers of the sea through a long water column and is sedimented to the sea floor. Selective dissolution, for example, reduces foraminiferal assemblages in the equatorial Pacific at the depth of Site 167 (3166 m) by up to $80 \%$ (Berger, 1971). Observational data indicate that radiolarian assemblages undergo the greatest dissolution in very shallow and very deep levels in the ocean (Peterson, 1969; Bukry et al, 1971; Kling, 1971). Selective

\footnotetext{
${ }^{1}$ Institute of Geophysics and Planetary Physics, University of California, Riverside, Contribution No. IGPP-UCR-73-15.
}

dissolution of calcareous nannoplankton generally increases with depth but extends below the compensation depth of foraminifera (Bukry et al., 1971). Unfortunately the details of these processes are not well known.

After burial, continued dissolution of microfossils, particularly foraminifera, causes a reduction in sediment volume by contributing to the collapse of the framework supporting tests of foraminifera which, in themselves, had a high original intratest porosity. Tests, weakened by dissolution and predation, become more susceptible to fragmentation which in turn leads to further reduction in sediment porosity. The broken tests and fragments in turn expose a greater surface area that enhances dissolution. Thus, the selective preservation of fossil assemblages that begins at the sediment/water interface is intensified during post-depositional diagenesis. Added to the effects of dissolution and fragmentation is the precipitation of calcite overgrowths on more stable skeletal elements and of calcite cement. The selectivity of these processes in destroying certain species, while leaving other species relatively unaffected, introduces an important bias which influences the interpretation of microfossil assemblages. At present, we are only beginning to perceive the extent of information loss and distortion resulting from this selective preservation.

From a paleontological viewpoint, the downhole change in microfossil preservation, as it is linked to lithification at Site 167, offers an opportunity to develop a basis for understanding the degree to which assemblages have been altered in comparable deposits such as the Cretaceous chalks and limestones of northwestern Europe and the Gulf Coast where the early phases of preservation no longer exist.

Based on the above observations, physical property measurements, and the geologic setting of the site, a diagenetic model is presented. The model involves, in terms of mineral transfer, solution of relatively unstable foraminiferal and, to a lesser extent, nannofossil calcite and the precipitation of the original skeletal calcite as more stable calcite overgrowths on nannofossils and as interstitial cement. During the solution-reprecipitation process, water is expelled and the porosity of the sediment is reduced. A simplistic model shows the process can operate without calcite being added to or expelled from the system.

The lithologic terminology used for the calcareous sediments follows that set forth by Gealy, Winterer, and Moberly (1971, p. 17). The Leg 17 convention for the main lithologies used aboard ship are: 
SITE 167

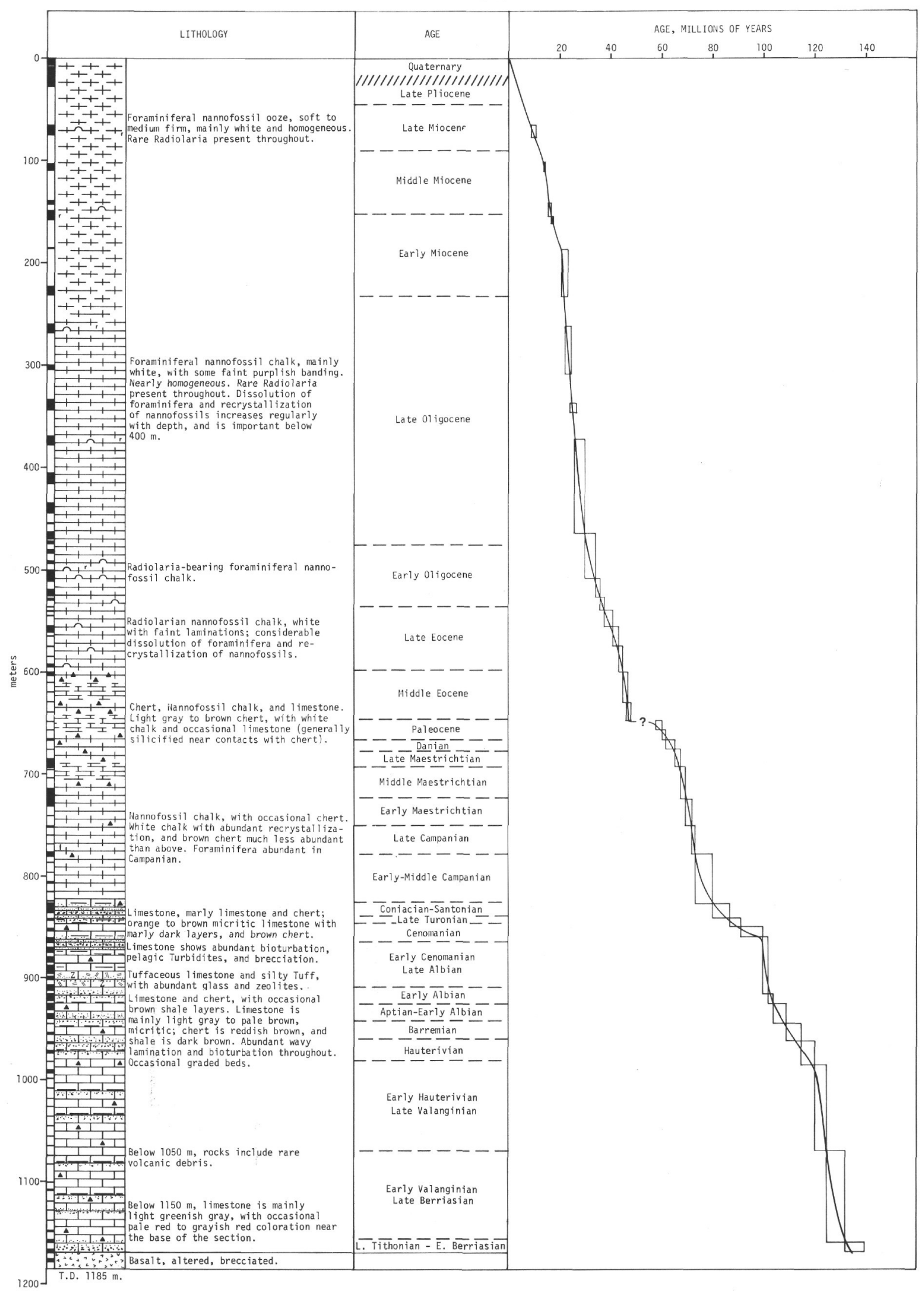

Figure 1. Stratigraphic section at Site 167. 
Ooze-easily deformable between fingers or under the broad blade of a spatula, plastic, easily cuttable, but does not chip or crumble (unless dried).

Chalk-slightly indurated, friable, can be deformed by the edge of a spatula, easily cuttable, but tends to chip or crumble.

Limestone-hard enough to be cut by a saw without disintegrating, not easily scratched by a fingernail or deformable. May emit a clear ring when struck.

The term micrite (micritic) is used to describe calcite grains only a few microns in size seen in smear slides. The grains have an irregular outline and can not be identified positively as nannofossils. The grains are probably formed by the breakdown of foraminiferal test wall calcite.

\section{METHODS}

The SEM studies were carried out using a JEOLCO SM-3 unit at University of California, Riverside. In the initial studies it was found that simply air drying the samples before they were gold-plated and mounted resulted in poor electron grounding in the SEM at voltages needed to obtain good resolutions. However, later runs using specimens that were treated in a low-temperature asher and then goldplated were more successful. It is thought that excess organic matter in the unashed specimens prevented them from receiving an adequate gold coating.

Qualitative estimates of the abundance and preservation state of each microfossil group were made during routine shipboard operations and later revised. Because each group was examined by a different worker and because different sampling and preparation techniques are used for each group, the abundance and preservation classes shown in Figures 2 and 3 are comparable but not identical.

The number of ostracods and benthonic foraminifera occurring in core-catcher samples is based upon picks made from the total greater than $100 \mu$ fraction from each sample; all recognizable specimens, broken and whole, are included.

The ratio of planktonic to benthonic foraminifera is based on microsplits of the greater than $150 \mu$ fraction and a minimum count of 500 specimens. Duplicate, triplicate, and, in some cases, quadruplicate counts were made of each sample and the results averaged. The counts shown in Figures 2 and 3 are for core-catcher samples, but in all cases comparable values were obtained from the normal core samples (this volume, Chapter 22).

The preservation scale used in Figure 2 for nannofossil assemblages is based on the following categories (Roth and Thierstein, 1972).

\section{Etching:}

E-1: slight etching, delicate features destroyed; pontosphaerids and rhabdosphaerids still present

E-2: most delicate species destroyed; increase in the percentage of solution-resistant species

E-3: only solution-resistant species left

\section{Overgrowth:}

0-1: slight overgrowth on discoasters and some coccoliths

0-2: arms of discoasters thickened, considerable overgrowth, covering central structures of coccoliths

$0-3$ : very strong overgrowth; many specimens cannot be identified
Data and interpretations relevant to this chapter are found in the following chapters in this volume: Chapter 5 , "Site 167"; Chapter 15 (Coplen and Schlanger); Chapter 20 (Douglas and Savin); Chapter 22 (Douglas); Chapter 23 (Roth); and Chapter 24 (Moore).

\section{STRATIGRAPHY OF SITE 167}

The sedimentary section at Site 167 is 1172 meters thick. It can be divided into four major lithostratigraphic units (Figure 1), and rests on basalt:

1) Quaternary to Early Miocene foraminiferalnannofossil ooze becoming chalky towards base of interval (0 to $220 \mathrm{~m}$ ).

2) Oligocene and Late Eocene foraminiferal-nannofossil chalk becoming radiolarian rich $(380 \mathrm{~m})$ in lower part of the interval ( 220 to $600 \mathrm{~m}$ ).

3) (a) Middle Eocene to Danian chalk, chert, and limestone; (b) Maastrichtian to Coniacian chert and chalk (600 to $827 \mathrm{~m}$ ).

4) Turonian to Tithonian chert, limestone, and marly limestone, including a thin tuffaceous layer in the late Albian (827 to $1172 \mathrm{~m}$ ).

The lithologic units correspond very closely to the acoustic units which are separated by prominent reflectors in the profiler record (see Site Report). These reflectors are persistent over large areas and are recognizable in the profiles obtained by R/V T. Washington near Site 167.

Two angular unconformities occur in the sedimentary section, corresponding to the boundaries between Units 1 and 2 and between 2 and 3 (Figure 1). The younger of these discordances correlates with the change from ooze to chalk at about 220 meters, close to the base of the Miocene. The recovered cores give no evidence that any biostratigraphic zones are absent, but the sediment accumulation rate curve (Figure 1) shows a change in slope at about this same level, from greater than $25 \mathrm{~m} / \mathrm{m} . \mathrm{y}$. in the Oligocene to less than $10 \mathrm{~m} / \mathrm{m} . \mathrm{y}$. in the Miocene. The angular relationship of the unconformity can be clearly recognized on the profiler records but only away from the summit areas of the rise, on the side slopes. A second unconformity is evident in the early Tertiary near the level of the Eocene cherts encounted at a depth of 600 meters.

There is no paleontological or petrographic evidence of shallow water at any time on Magellan Rise. The benthonic foraminiferal assemblages suggest bathyal or greater depths since the late Cretaceous (Chapter 21, this volume).

High sedimentation rates result in quick burial and better preservation (Tracey et al., 1971). However, hiatuses which develop during periods of low or zero net accumulation also represent periods when surficial sediments are exposed to severe diagenetic effects involving solution at suitable bathymetric depths, bioturbation, and predation. Average sediment accumulation rates calculated for the prominent lithologic units in the section indicated the following downhole variations:

0 to 220 meters: foram-nannofossil ooze and chalky ooze: The average sediment accumulation rate is about 9 $\mathrm{m} / \mathrm{m} . \mathrm{y}$. The low rate of sediment accumulation for the Late Miocene and Pliocene suggests the possibility of a hiatus in the section between Cores 3 and 4 . Hiatuses at this level have been found at other sites in the equatorial Pacific (Winterer et al., 1971). 


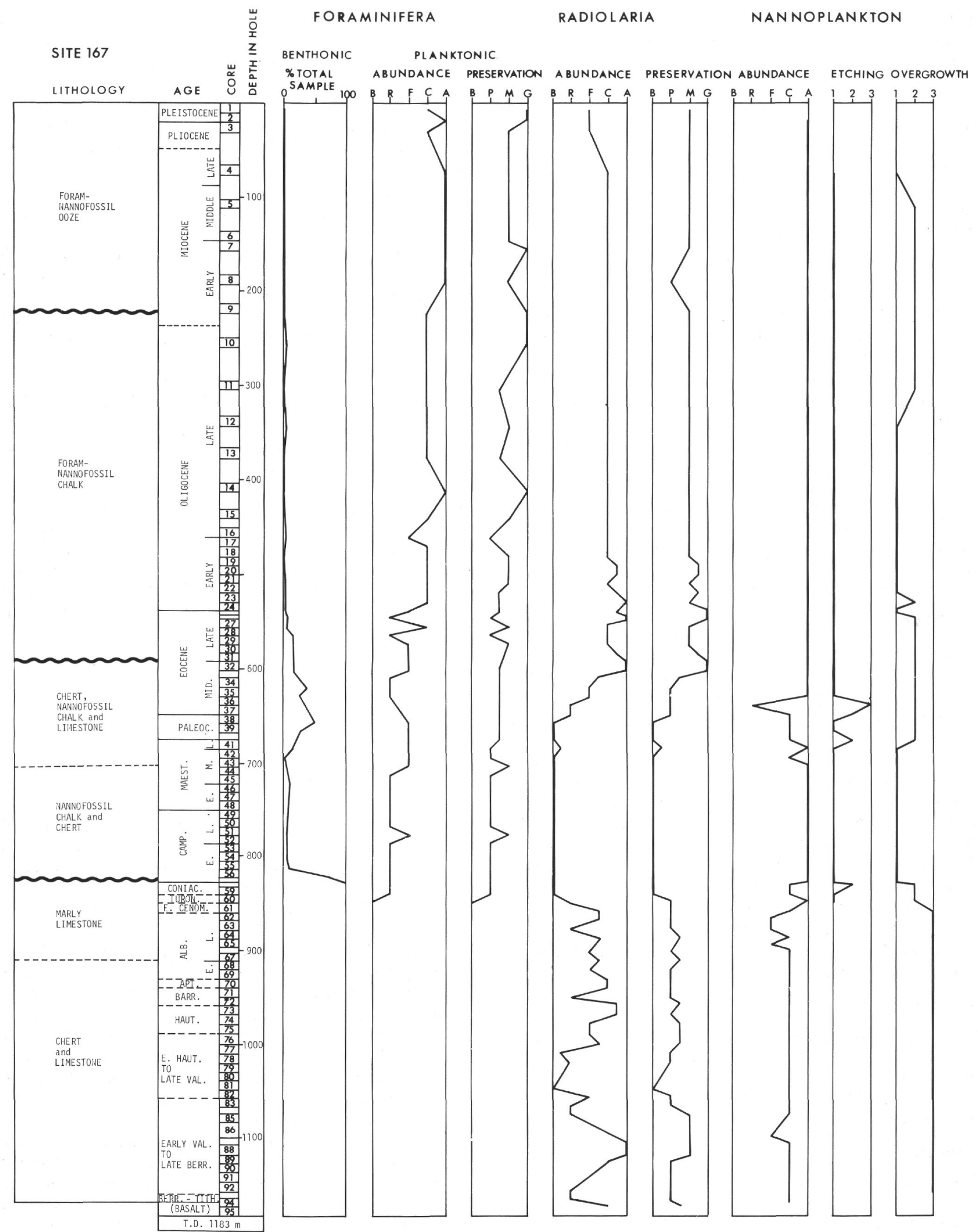

Figure 2. Abundance and preservation plots for foraminifera, Radiolaria, and nannofossils, Site 167. 
FOSSIL PRESERVATION AND DIAGENESIS OF PELAGIC CARBONATES

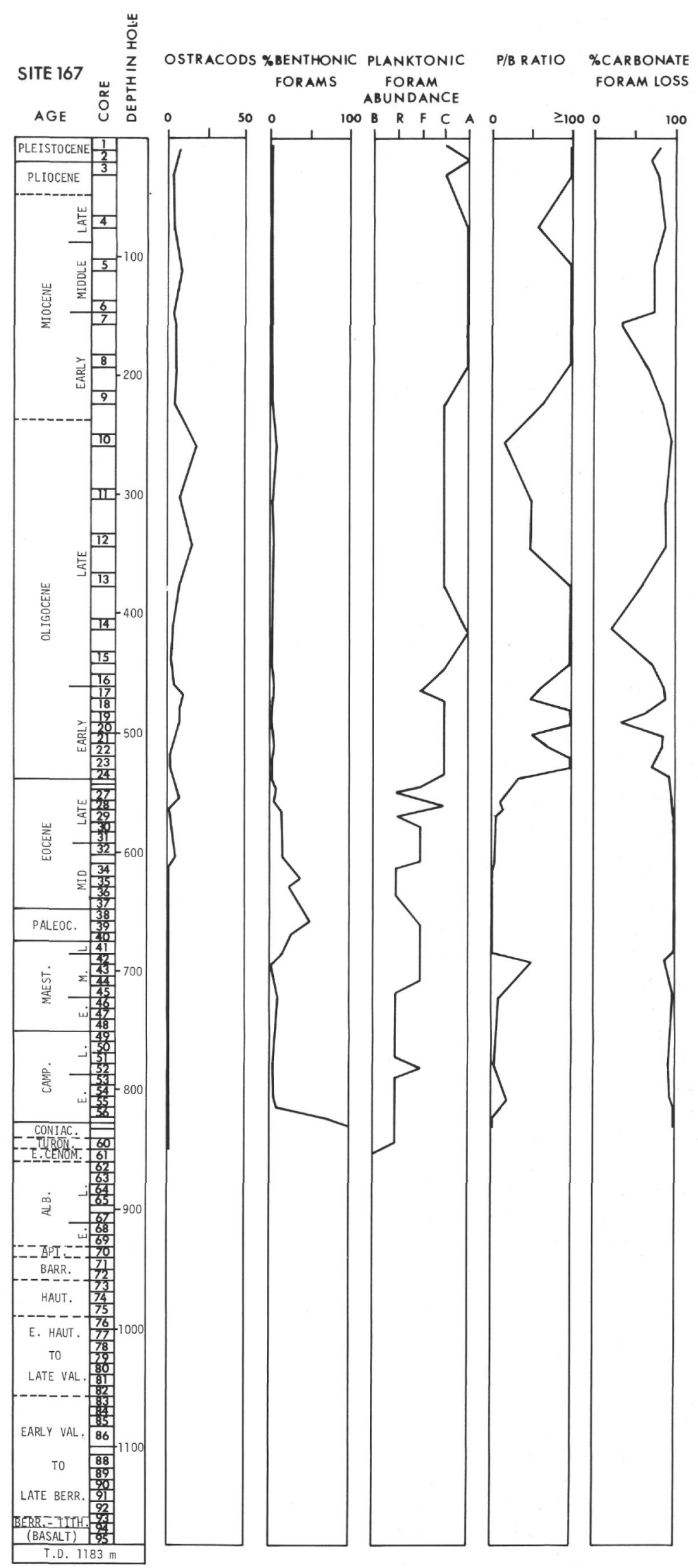

Figure 3. Abundance and preservation of ostracods and foraminifera, Site 167. 
220 to 600 meters: foram-nannofossil chalk: The average sediment accumulation rate is about $18 \mathrm{~m} / \mathrm{m} . \mathrm{y}$. The accumulation rate is particularly high in the Late Oligocene.

600 to 710 meters: chert, nannofossil chalk, and limestone: The average sediment accumulation rate for this interval is about $3 \mathrm{~m} / \mathrm{m} . \mathrm{y}$. Hiatuses are identified in the Lower Eocene and Paleocene.

710 to 827 meters: nannofossil chalk and chert: The average sediment accumulation rate for this part of the section is about $8 \mathrm{~m} / \mathrm{m} . \mathrm{y}$.

827 to 916 meters: marly limestone: The average sediment accumulation rate is about $5 \mathrm{~m} / \mathrm{m}$.y. Hiatuses are present in Santonian and Upper Cenomanian parts of the section.

916 to 1185 meters: chert and limestone: The upper part of this interval has a sediment accumulation rate of about 3 $\mathrm{m} / \mathrm{m}$.y. and hiatuses may be present particularly in the upper Valanginian to lower Hauterivian. The lower part of the interval has a sediment accumulation rate of about 14 $\mathrm{m} / \mathrm{m} . \mathrm{y}$.

\section{PETROGRAPHY}

The important changes that occur in the sediments with increasing age and depth of burial are the consequence of diagenetic processes, namely, lithification and silicification. Because the major lithologic changes are generally abrupt and well defined in the cores and because they correspond remarkably well to the principal reflectors observed on the seismic profile, it was convenient to divide the entire section in the four lithostratigraphic units noted above.

\section{Foraminiferal-Nannofossil Ooze (0 to 220 meters)}

These sediments consist mainly of white calcareous nannofossils and foraminifera. Radiolaria are regularly present in small but variable amounts. The breakdown of foraminifera tests and the overgrowth of nannofossils were first noticeable in smear slides from Core 4. Numerous well-crystallized calcite fragments (silt size) that are probably fragments of large-sized planktonic foraminifera were observed in several smear slides.

No primary structures were observed in the ooze which is commonly disturbed badly by the drilling process.

Sample $167-5-3,132 \mathrm{~cm}$ is a plastic, white ooze. The sediments are made up of randomly oriented coccoliths all of which show well-preserved, distinct sutures and foraminifera (Figures 4 and 5). Individual coccoliths range from 3 to $10 \mu$ in diameter. Many of the individual discs are broken and many recognizable segments are scattered throughout the sample. Scattered on the surfaces of many coccoliths are small, 1 to $5 \mu$, subhedral crystals of calcite (?). These stubby, equant crystals might represent the results of fragmentation and dissolution of coccolith elements.

Overall foraminiferal preservation is good to excellent. Planktonic species are chalky in appearance, particularly the species least resistant to dissolution (Globigerinoides) but holes, etc. are not apparent. Photomicrographs reveal etched surfaces, but no sign of overgrowths. Benthonic species are no longer shiny or glassy in luster, which is also a sign of etched surfaces. High-magnesium benthonic species are reduced to chalky fragments.

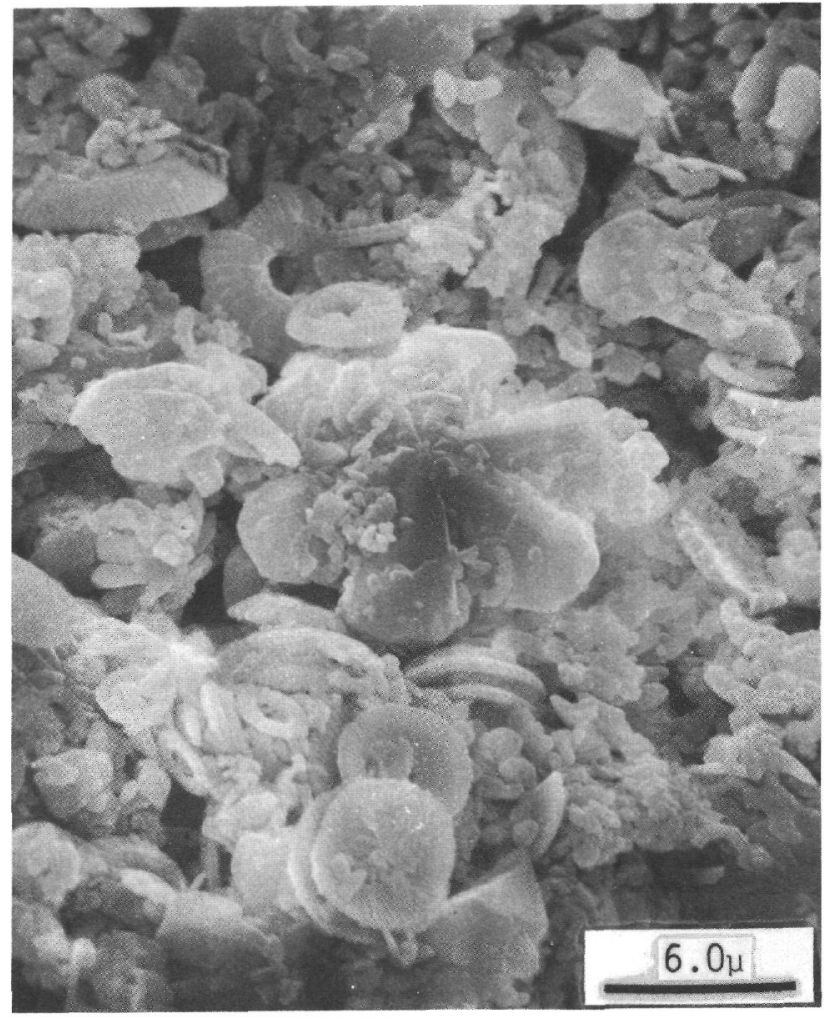

Figure 4. Foraminiferal-nannofossil ooze of Middle Miocene age (Sample 167-5-3, $132 \mathrm{~cm}$ ) loosely packed coccoliths (mostly Cyclicargolithus floridanus) showing wellpreserved sutures. Note the abundance of subhedral calcite produced by the breakdown of coccolith elements and foraminifera tests.

\section{Foraminiferal-Nannofossil Chalk (220 to 600 meters)}

The transition from ooze to chalk appears gradational. The plastic oozes in Cores 1 through 4 became firmer and chalkier through Cores 6, 7, 8 and 9; the highest definite hard chalk lumps occurring in the lower part of Core 9 (and possibly some in Core 8 ). Because this zone corresponds to a relatively sharp and well-defined reflector and perhaps to an unconformity traceable on seismic profiles in the vicinity of the site, it is probable that the gradational contact between ooze and chalk is due mainly to drilling disturbances.

The chalk is generally firm, white, and almost homogeneous in the upper part, but shows faint laminations and purplish banding in the lower part. These slight changes of coloration result from the presence of fine-grained iron and manganese oxides and possibly pyrite.

The composition of the upper layers of the chalk is somewhat similar to that of the oozes above, with abundant calcareous nannofossils and foraminifera and rare Radiolaria. The foraminifera very commonly show traces of dissolution, and the nannofossils are generally recrystallized. Micritic small grains of calcite, which are probably the cement of the chalk, are common to abundant in most smear slides. Below Core 19 (around $490 \mathrm{~m}$ ) the proportion of Radiolaria increases noticeably, whereas that of the foraminifera decreases slowly at first and then sharply after Core $24(530 \mathrm{~m})$. 


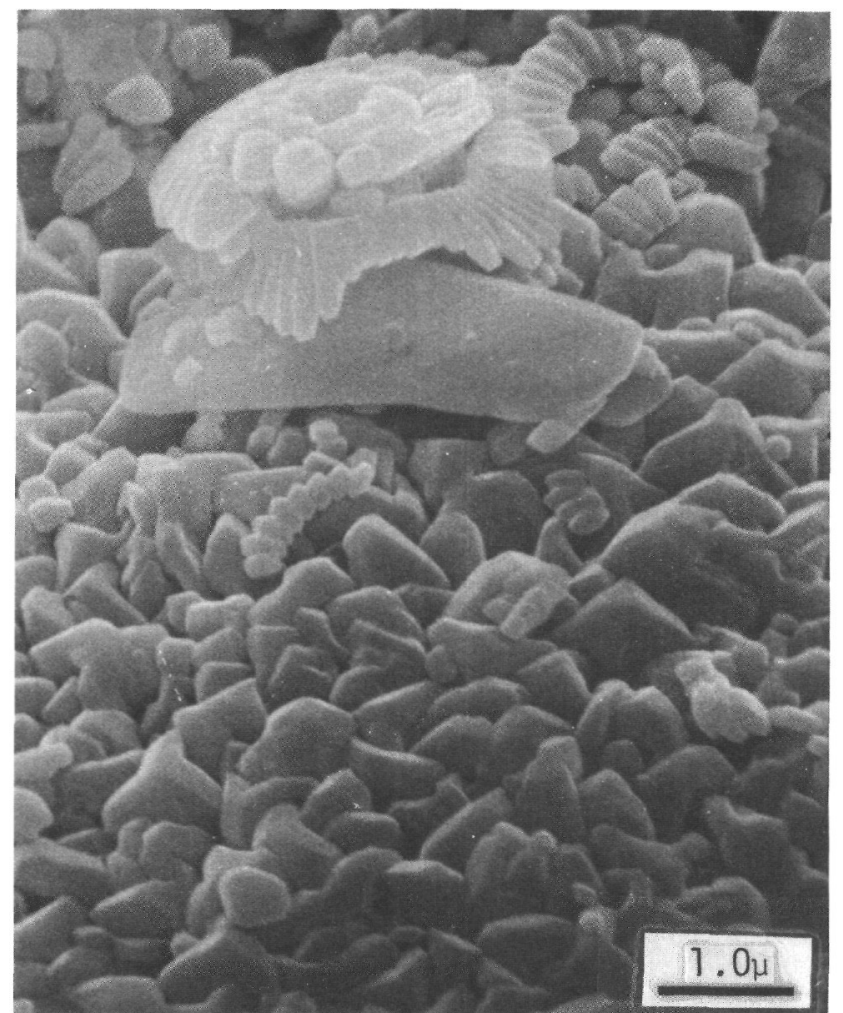

Figure 5. Same sample as Figure 4. High magnification view of the surface of a foraminifera test showing typical solution texture.

Samples from Sections 167-9-4 and 167-15-4 are representative of the chalks. Core 9 was taken in the transition zone of early Miocene age between the plastic oozes and the firm chalks, whereas Core 15 was taken in the chalks of Late Oligocene age. Figures 6 and 7 show the salient features of sediments from Core 9; well-preserved coccoliths are in intimate association with nannofossil elements that show overgrowths. The tests of foraminifera have been altered so that the outer surfaces are grainy and porous. The sample from Core $15-4$ is dominated by coccoliths although some foraminifera are present. The coccoliths are well preserved, sutures are distinct, and only minor solution features are noted. Megascopically the rock is a very friable, pure white, massive chalk with tests of planktonic foraminifera visible. As shown in Figure 8, the foramina of the tests are open and the test wall appears as a granular mosaic. The tubular elements of the inner cycle surrounding the central hole of the most common placoliths are partly dissolved and some show secondary growth (Figures $8,9,10)$. Individual coccoliths are partially disintegrated (Figures 8 and 9); discrete rings of the radially arranged segments are in part broken up, producing slightly elongated calcite prisms. Parts of the sample appear to have a lower porosity due to the abundance of evenly sized 0.4 to $0.6 \mu$ anhedral calcite prisms that are locally densely packed. These may be calcite cemented. Note that the coccoliths still show well-defined sutures, but individual fragments of coccoliths are difficult to distinguish against the background of fine-grained particles. These consist mostly of coccolith debris covered with secondary calcite

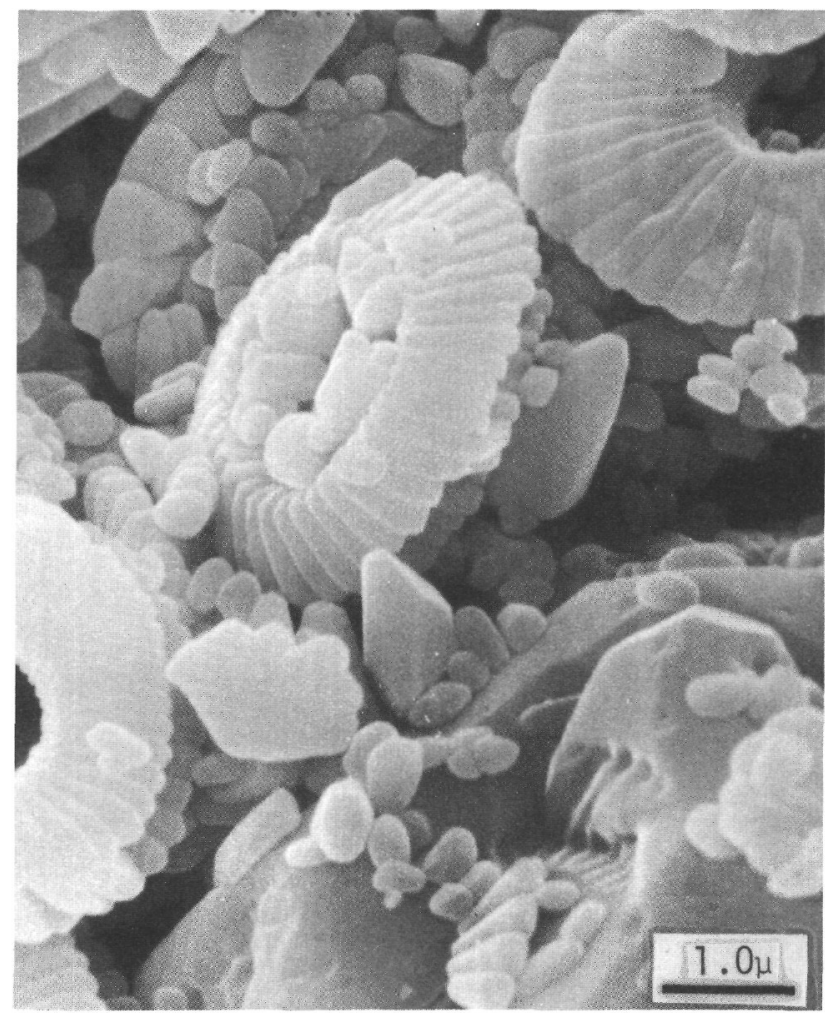

Figure 6. Foraminiferal-nannofossil chalk of Early Miocene age (Section 167-9-4). Relatively well-preserved coccoliths with anhedral grains of calcite formed by the breakdown of elements and euhedral calcite formed by overgrowth.

which obscures primary ultrastructural details. Solution features are very abundant on both planktonic and benthonic species. Pitting, etching, and breakage are common; holes in the inner chambers are present on some thin-walled planktonic species. Broken benthonic species are common, especially thin or long-shaped forms and species with thin walls and large pores. There is minor calcite infilling of the chambers of planktonic species and overgrowths on the inner shell and pores.

Sample 167-23-CC is made up of randomly oriented coccoliths that in general display well-preserved sutures (Figure 9). Some of the coccoliths show a breaking down or recrystallization of parts of the inner cycles. In these areas the shield structures are not perfectly regular. Although they still retain a segmented appearance, each segment is irregular and patchy. In addition to recognizable coccoliths, a significant part of the sediment is made up of stubby, equant to slightly elongated subhedral crystals of calcite that range from 0.3 to $0.6 \mu$ in length. In parts of the sample these crystals make up approximately $35 \%$ of the rock. In other parts the crystals appear as patches of several dozen discrete, but touching, crystals coating coccoliths. Some of the coccoliths appear frayed; their edges are irregularly serrated, and the individual segments of the annular rings are uneven. Fragments of tests of planktonic foraminifera are present. These are similar to those seen in Core 167-15; more evidence of overgrowths, cementation, and recrystallization. Foram assemblages have much the same aspect as 


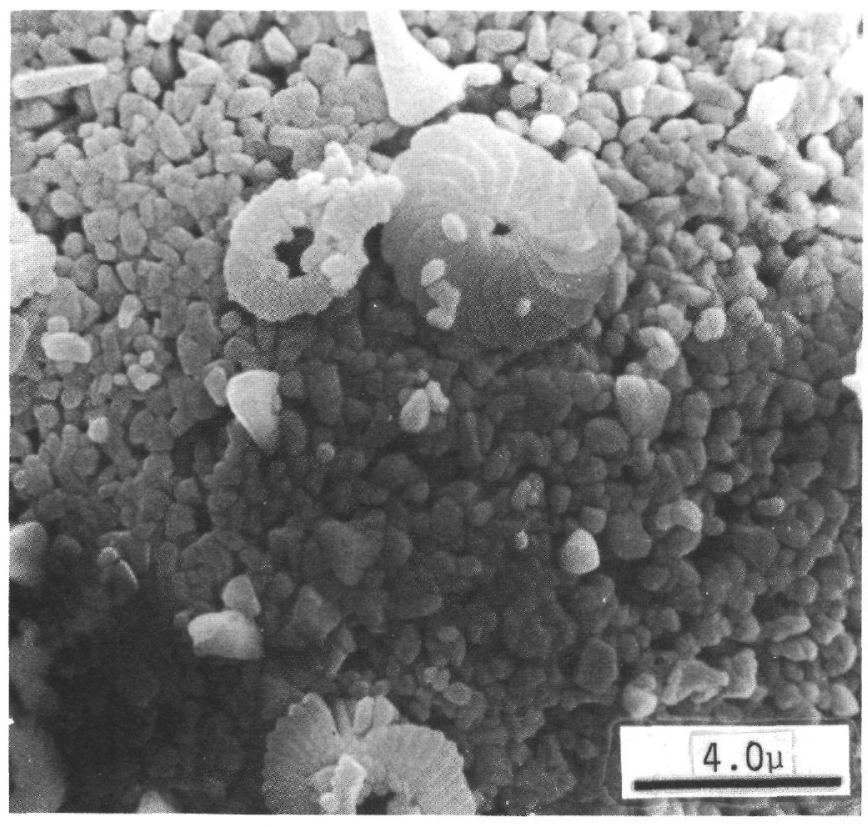

Figure 7. Same sample as Figure 6. Outer surface of test of foraminifera showing granular texture due to dissolution.

Cretaceous assemblages from the softer chalks of Europe or the Gulf Coast and are dominated by large, thick-walled species. Benthonic species exceed $30 \%$ of the total assemblage. Many are partial recrystallized or have overgrowths which give them a drusy texture. The assemblage is dominated by species which are more resistant to breakage.

\section{Nannofossil Chalk, Chert, and Limestone (600 to 827 meters)}

The chert is particularly abundant in the upper portion of this interval, but below Core 44 (around $710 \mathrm{~m}$ ) it is present in lesser proportions and persists down to the basement. It is a massive, hard, glassy, chalcedonic chert with conchoidal fracturing. Its color (gray to pale brown) reflects generally the color of the sediments in which it lies, with a somewhat darker tone. Many pieces show remnants of bedding as well as limestone inclusions.

The chalk that predominates from Core 44 down to Core 56 ( 710 to about $820 \mathrm{~m}$ ) has a composition slightly different from that of the overlying interval. Radiolaria are generally very rare and disappear completely below Core 38. Foraminifera are generally common and some of them are silicified; they decrease in abundance in the lower cores ( 52 to 56 ), which contain some slightly hematitic clay that gives the cores a pale brown color. Sample 167-35-CC was chipped from the dense, white, very hard silicified chalk ring that surrounded a fragment of gray chert. It is from the intermediate zone between the pure chert and the softer unsilicified chalk that surrounds the chert in the section drilled. Coccolith remains are abundant: however, they are poorly preserved. The plate segments are very blocky (Figures 10 and 11). Much of the sample is made up of very angular fragments which are the size and shape of individual segments or fragments of segments of coccoliths. Also seen are structures interpreted as completely recrystallized radiolarian or foraminifera tests (Figure 11). The former test is now made up of radially arranged, doubly terminated quartz (?) crystals 2 to $3 \mu$ in length, whereas the interior of the test has been filled with larger crystals of indeterminate composition. Small patches of quartz (?) crystals are also seen in the matrix.

The chalk from Core 41 was of interest because it was very crumbly and friable-almost an ooze. However, the smear slide revealed abundant micrite interpreted as recrystallized nannofossils (?). In addition, foraminifera and coccoliths were common. SEM studies show that much of the sediment (Figure 12) is made up of stubby equant, subhedral to anhedral grains of calcite. Closer examination revealed that the foraminifera have been completely infilled by calcite overgrowths (Figure 13).

\section{Limestone and Chert (827 to 1172 meters)}

These rocks are indurated and show well-preserved primary structures. They are generally light colored (white, light gray, pale brown, and pale green), the darker rocks being generally slightly enriched in clay and minerals of volcanic origin. Most of the section shows faint laminations that generally have a "wavy" aspect that may be due partly to bottom-current circulation, but probably mainly to bioturbation or compaction. Burrows are generally abundant, and many show deformation by compaction. Turbidites occur throughout the interval. Some of them consist of graded sequences, the lower lower portion of which is composed of flattened, small lithified mud pebbles that pass progressively upward to more-or-less homogeneous sediments. Burrows and "wavy" laminations at the top of sequences mark the return to pelagic sedimentation. Other sequences show graded beds of silicified foraminifera and/or Radiolaria. The thickness of the sequences varies from a few centimeters to about $20 \mathrm{~cm}$. In Core $63 \mathrm{a}$ pebbly mudstone occurs which may be the result of a more massive displacement of sediments. In several cores the presence of probable slumping (in units up to about 1 meter thick) is evidenced by steeply dipping bedding planes (up to $47^{\circ}$ ) and "fluidal" textures. The turbidites consist exclusively of redeposited pelagic material. They probably account for part of the filling of the basement depressions that appear on the seismic profile.

In the upper part of this interval the limestone is generally marly and owes its reddish brown color to the presence of hematite. Clay-rich, dark brown to black beds probably contain some manganese oxides. Generally, smear slides from the limestones contain mainly micritic grains of calcite, common to abundant recrystallized nannofossils, and some silt-size sparry, commonly rhombic calcite grains. The shape of these crystals, as well as that of other small rhombs in the fine-grained material, suggests the possible presence of dolomite, although the acetic acid tests were negative.

Cores 65, 66, and 67 sampled a dark green silty tuff zone, several meters thick, that contains abundant volcanic glass and zeolites. In the section below, the limestone is generally light gray to pale brown, and clay minerals are 


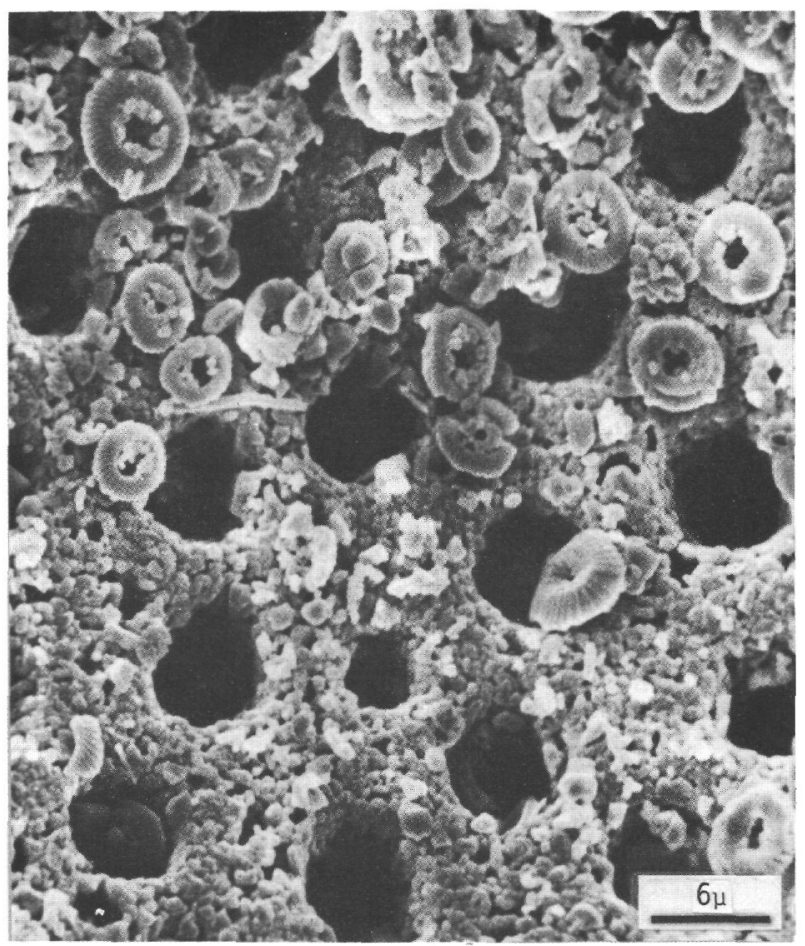

Figure 8. Foraminiferal-nannofossil chalk of Late Oligocene age (Section 167-15-4). Inner wall of broken foraminifera test showing etched character of the wall. Packed around the outside of the test are Cyclicargolithus floridanus and Coccolithus eopelagicus. The plates around the central hole are an etched inner cycle of $\mathrm{C}$. eopelagicus. Some of the cycles of elements are broken producing smaller prisms of calcite.

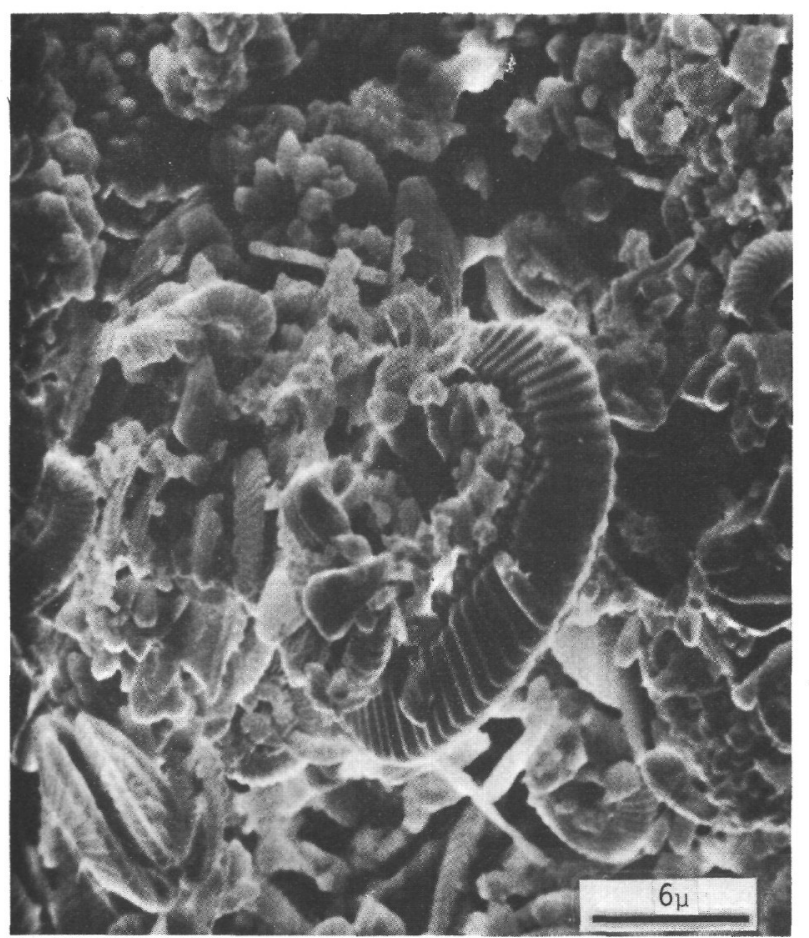

Figure 9. Foraminiferal-nannofossil chalk of Early Oligocene age (Sample 167-23, CC). View of single coccolith (Reticulofenestra umbilica). Note the slightly irregular growths of the tabular elements constituting the basic cycle surrounding the central area. The majority of the smaller coccoliths belongs to Cyclicargolithus floridanus.

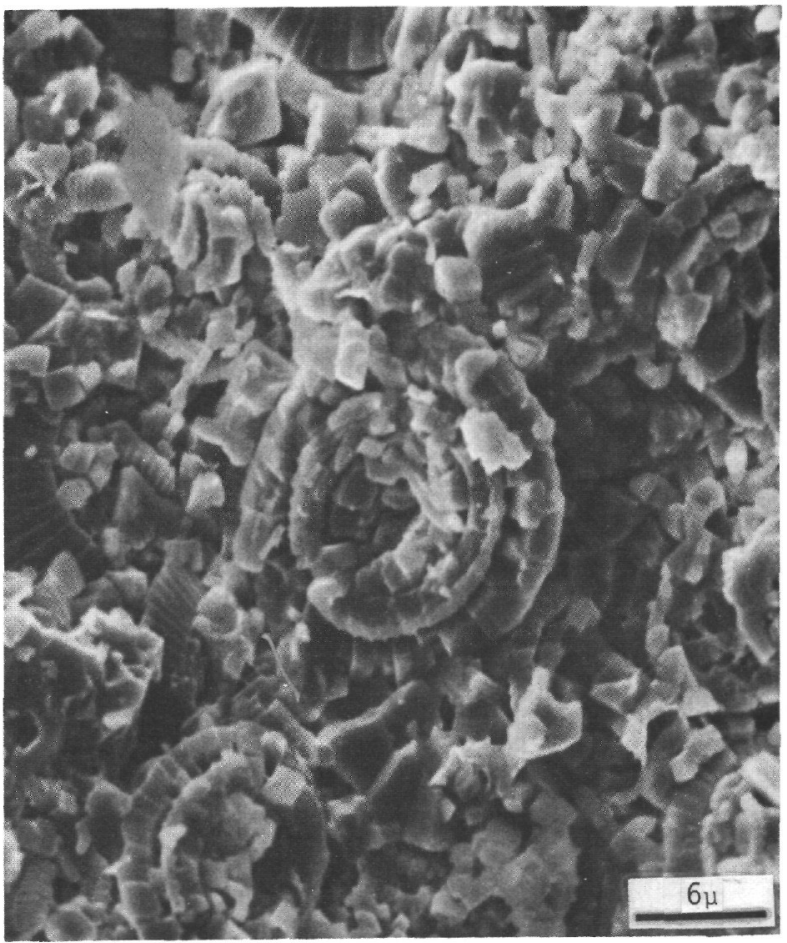

Figure 10. Silicified nannofossil chalk of Middle Eocene age (Sample 167-35, CC). The coccoliths in the center and in the upper left are proximal views of Coccolithus eopelagicus. These show secondary growth of the elements in all of the cycles and the central arc, giving them a blocky appearance. The matrix consists of blocky and angular fragments and cement.

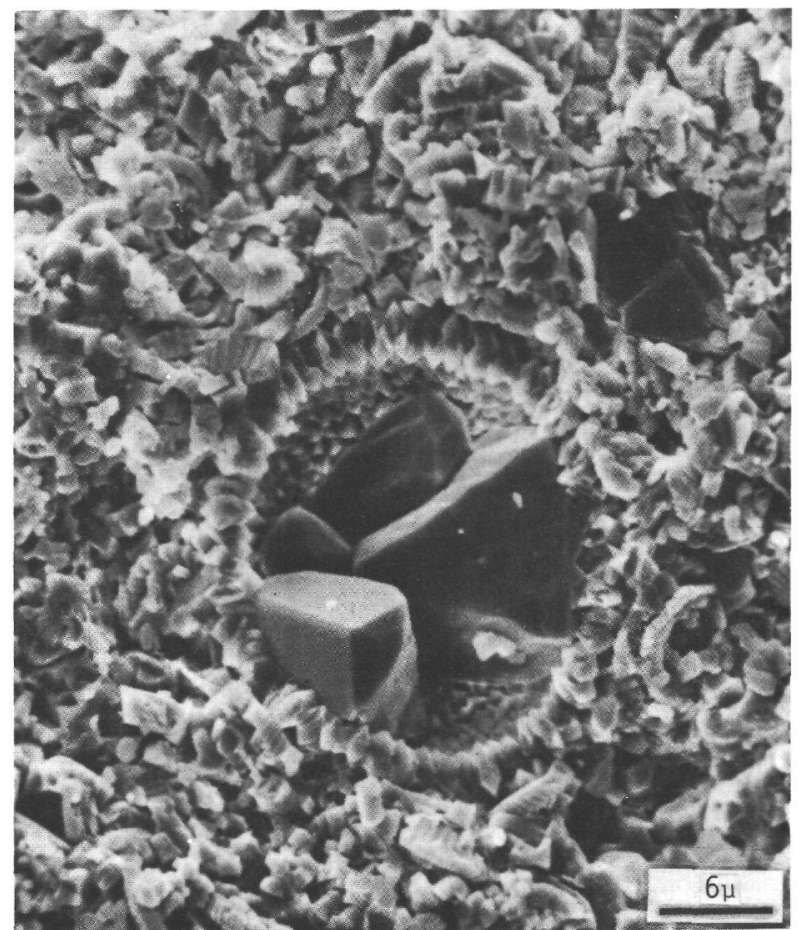

Figure 11. Same sample as in Figure 10. Replaced, recrystallized radiolarian test. A shell of radially oriented, doubly terminated quartz (?) crystals surrounds a coarser group of quartz (?) crystals. 


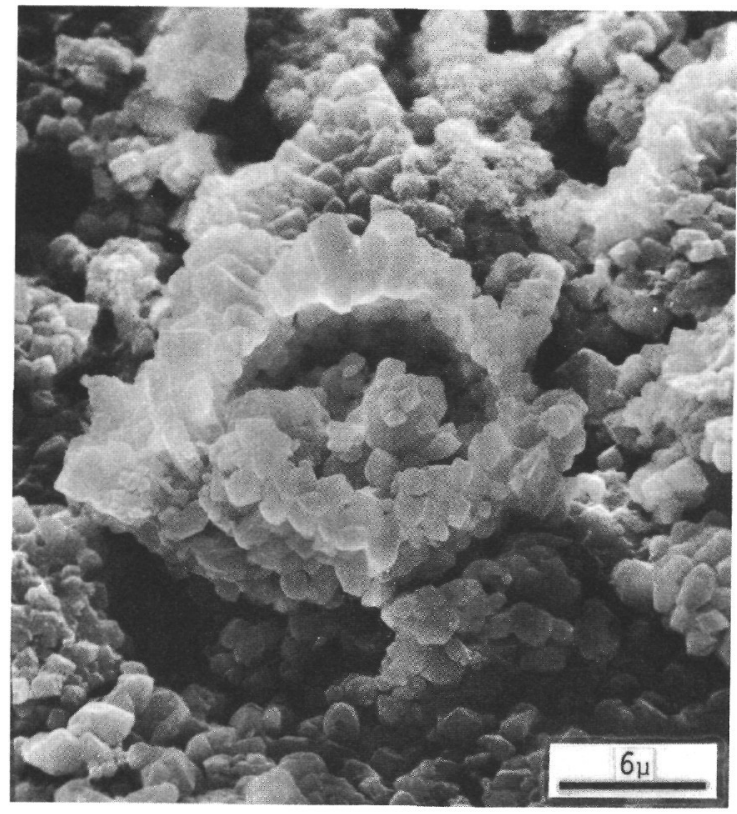

Figure 12. Nannofossil chalk of Late Maastrichtian age (Section 167-41-4). View of broken spherical hollow mass of radially arranged calcite crystals. This structure is interpreted to be the result of intense recrystallization of a planktonic foraminifera test.

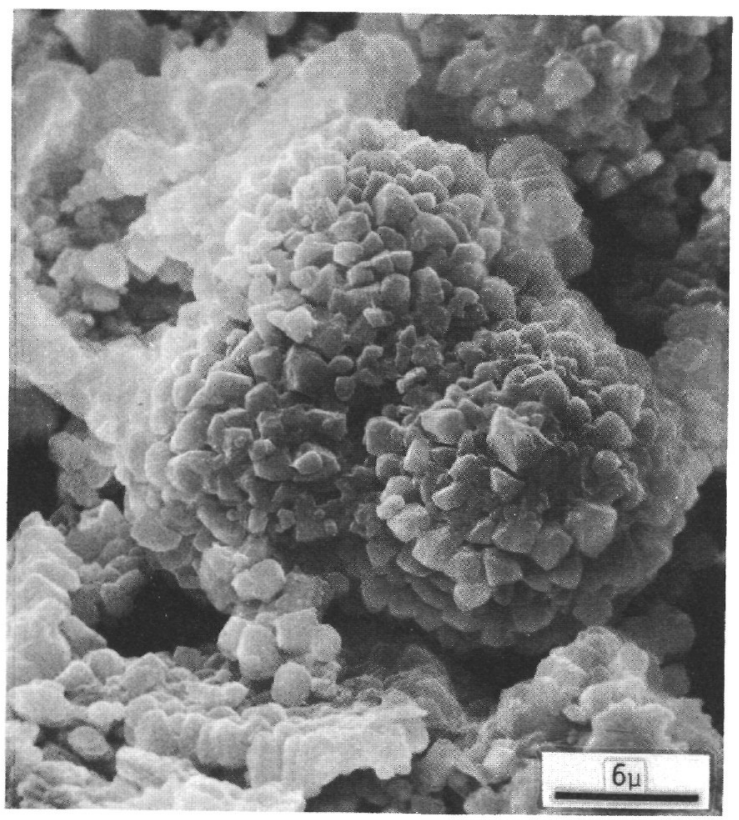

Figure 13. Same sample as in Figure 12. View of the exterior of an intensely recrystallized foraminiferal test. Euhedral crystals radially arranged suggest that overgrowths, initiated on original crystals in the test, probably lead to this form. In the lower part of the picture a fragment of a test is seen. These tests have partially broken down producing the masses of subhedral crystals that make up the sediment.

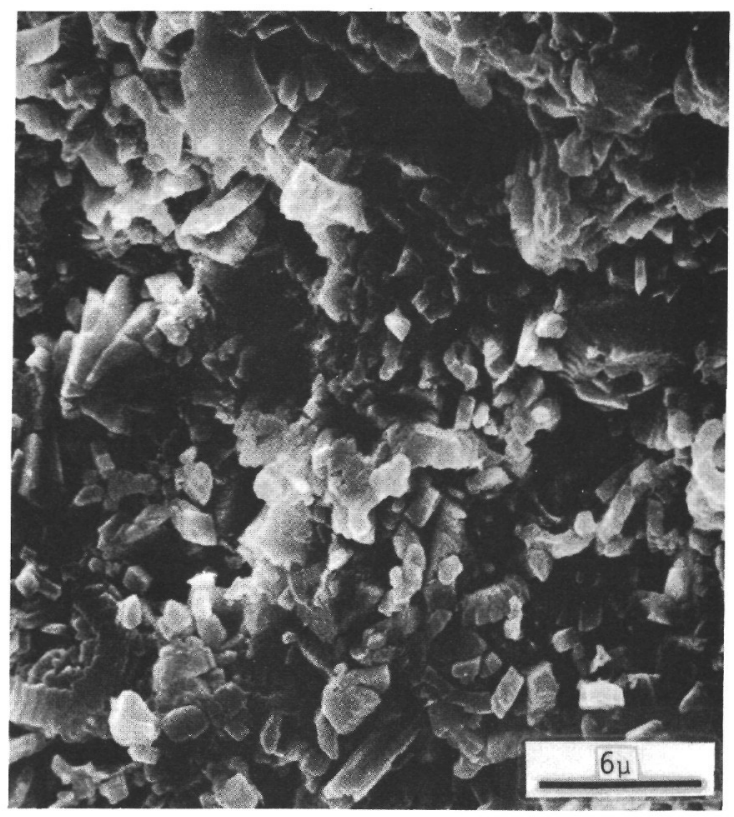

Figure 14. Nannofossil limestone from Section 167-71-1 showing etched and overgrown coccoliths in a matrix of disaggregated coccoliths and cement.

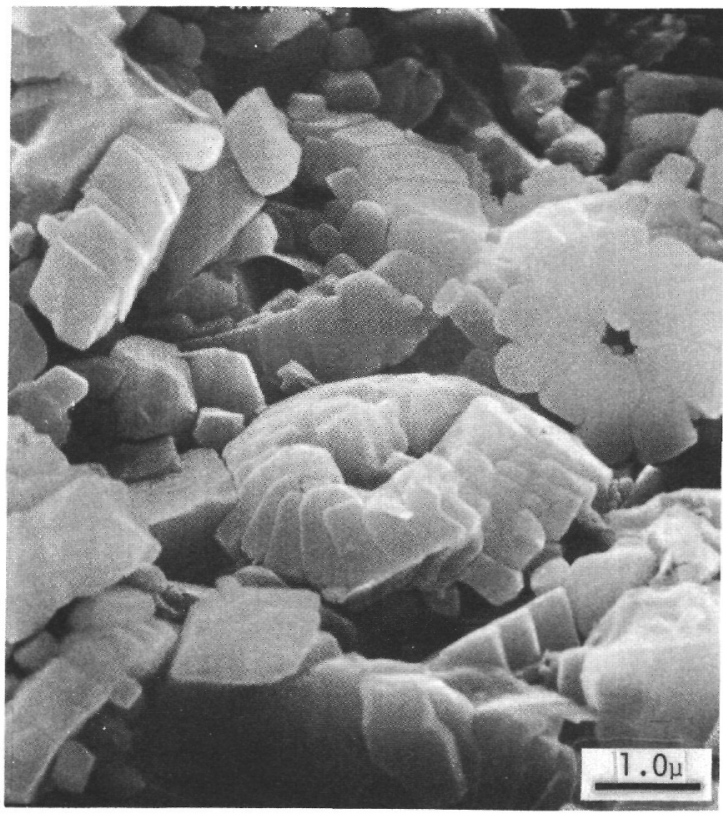

Figure 15. Calcite-cemented nannofossil limestone (Section 167-78-1). Overgrown and etched coccoliths showing interpenetration with calcite cement and possibly other recrystallized coccoliths. 
concentrated in thin shale layers, together with zeolites and iron (and $\mathrm{Mn}$ ?) oxides.

Between Cores 78 and 91 (1010 to $1140 \mathrm{~m})$, the recovery was very poor and chert again appears dominant. The dominance is probably artificial and might indicate a zone of unsampled softer sediment in this interval.

Tuff was also observed in the core catcher of Core 90, but owing to very poor recovery, the mixing of several lithologies, and the small size of the fragments obtained, this material may, in fact, be only cavings from farther up the hole.

The last three cores recovered above the basement yielded. mainly greenish limestone with some grayish red layers toward the bottom. These limestones contain volcanic detritus. They are very hard, but no evidence of any thermodiagenetic process could be found in them. In fact, calcite is even less recrystallized in these layers than in the upper portion of the limestone section. This observation suggests that the basaltic rocks immediately below are extrusive rather than intrusive.

In Section 167-71-1 numerous coccoliths in a matrix of disaggregated coccoliths and cement (Figure 14) are present. Many have been reduced to thin spiked toroidal shapes. Locally, there is blocky subhedral to euhedral clusters of calcite cement. Core 78 contained gray, aphanitic recrystallized nannofossil limestone marked by a stylolite seam at $145 \mathrm{~cm}$, indicating strong solution of part of the section. Chert was also recovered as pieces. SEM photos show these limestones to be well cemented (Figures 15 and 16). Interpenetration of nannofossils and cement is clearly seen.

Rocks recovered in Core 81 are hard, dense, very fine-grained nannofossil limestones. SEM studies show that cement is prominent (Figures 17, 18, and 19). Nannofossils are still easily recognized, but the cement locally dominates. Further the cements are rather euhedral. The size and shape of some of these calcite masses (Figure 17) suggest that they are completely recrystallized and filled tests of organisms. The coccoliths are severely etched and overgrown by calcite. Section 167-94-2 is a very dense hard limestone that shows a subconchoidal fracture and is light gray to light gray-green in color. Under the SEM very strongly etched coccoliths are seen (Figure 20). Most of these have been reduced to toroidal-shaped remnants. Also present are slightly etched nannoconids. These fossils are packed in a dense matrix of subhedral to euhedral crystals of cement. Some of the crystals show a tendency to a rhombic habit. Also present are crystals made up of bundles of laths; these may be the noncarbonate minerals that give the rock its greenish cast.

\section{Summary}

The ooze shows relatively unaltered nannofossils and foraminifera. The first step in the lithification process appears to be the partial dissolution of the foraminifera and the recrystallization of the nannofossils (which are still discrete individuals). The chalk is characterized by a general recrystallization of the nannofossils; the dissolution of the foraminifera, which commonly are well preserved only where silicified; and the appearance of small (clay-size to silt-size) calcite grains, probably recrystallized from dis- solved foraminifera and nannofossils. In the limestone, the dominant component is the recrystallized micritic calcite with only a few foraminifera (mainly silicified). Nannofossils, though recrystallized, are generally still common.

\section{FOSSIL PRESERVATION}

\section{General Observations}

Examination of the sediments from Site 167 shows that the downhole change from biogenous ooze to chert and limestone is accompanied by a reduction of the microfossil content of the sediments. Diagenesis affects each microfossil group somewhat differently, and a plot of abundance and state of preservation, estimated for core-catcher samples, shows an inverse relationship between foraminifera and Radiolaria. The downhole changes in microfossil content and preservation are gradual and correspond closely to the lithologic transition from ooze to chalk to limestone.

In the Neogene ooze all of the microfossil groups are generally well preserved and common or abundant. An exception occurs at the top of the hole, in Cores 1 and 2, where foraminifera exhibit signs of dissolution and Radiolaria are sparse. These features are believed to be a result of original sedimentation regimes.

With the change from calcareous ooze to chalk in the Oligocene, foraminiferal abundance decreases, preservation becomes poorer, and this trend continues into the Eocene. Foraminifera are absent in Cores 35 to 37 ; the first limestone was recovered in Core 36 . In a few cores before their disappearance in the section, in Core 33 , recrystallized foraminifera were noted. The change in preservation in the Oligocene may be related to the noticeable pyrite content in the rapidly accumulated sediments in Cores 9 to 15 . Foraminifera reappear in the section in the Danian, Core 39 , and repeat the pattern described above as the sediments change from marly limestone and chalk to limestone in the Upper Cretaceous. Two differences are apparent, however. First, foraminifera are sparse in all of the Cretaceous cores and, second, planktonic species drop out well in advance of the benthonic species, in Core 55. Cores 57 to 60 contain only benthonic species, and they are recrystallized with a drusy texture.

Radiolaria exhibit trends in preservation and abundance which are roughly inverse to those of planktonic foraminifera. Unlike foraminifera, however, changes in the siliceous fossils occur in rapid shifts. Concomitant with the decrease in foraminifera in the Lower Oligocene-Upper Eocene, Radiolaria increase noticeably, and these assemblages are well preserved. However, following the appearance of chert in Core 32, Middle Eocene, Radiolaria rapidly disappear from the section. No Radiolaria occur between Core 38 and Core 60. Below Core 60, which contains the last calcareous foraminifera, Radiolaria occur in small numbers to the base of the hole, except for a thin layers associated with chert nodules where they may be abundant (Figure 2).

The major changes in radiolarian abundance are closely related to the occurrence of chert in the section. Calcareous nannofossils are the most resistant and preservable microfossil. Changes in nannofossil preservation correlate with the shifts in radiolarians rather than in foraminifera. 


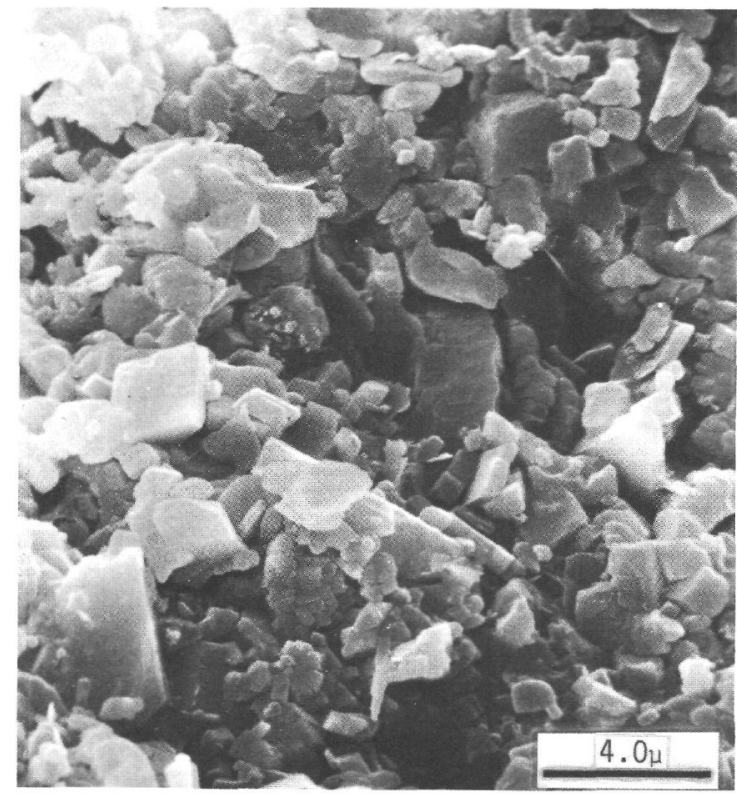

Figure 16. Calcite-cemented nannofossil limestone (Section 167-78-1). Coccoliths are imbedded in mass of subhedral to euhedral, locally rhombic (dolomite?) cement.

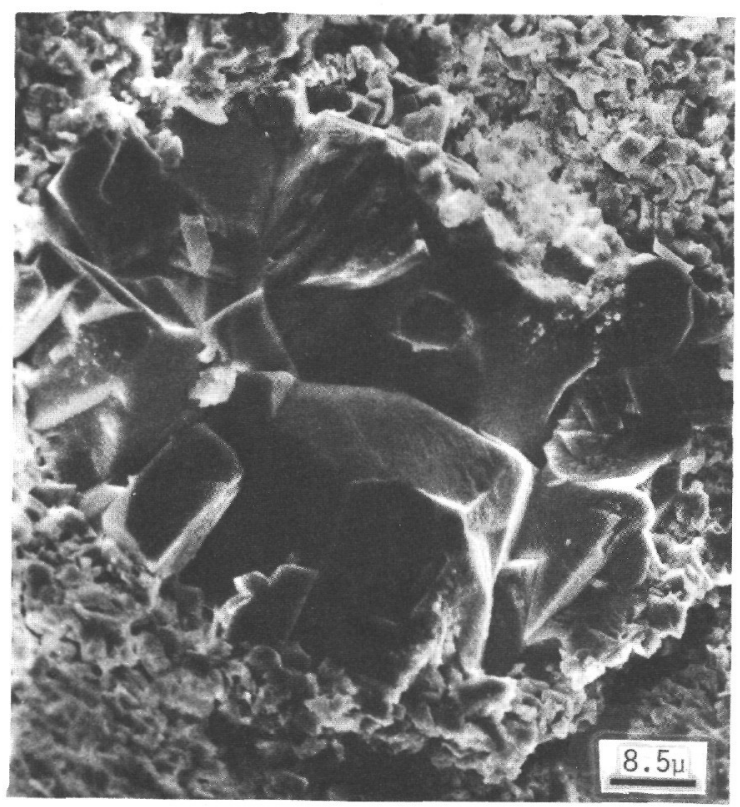

Figure 17. Limestone of Valanginian-Hauterivian age (Sample 167-81, CC). Avoid mass of calcite crystals that appear to have grown in a void probably a former site of a foram or radiolarian test. Groundmass is a closely packed arrangement of coccolith fragments and fine-graded cement.

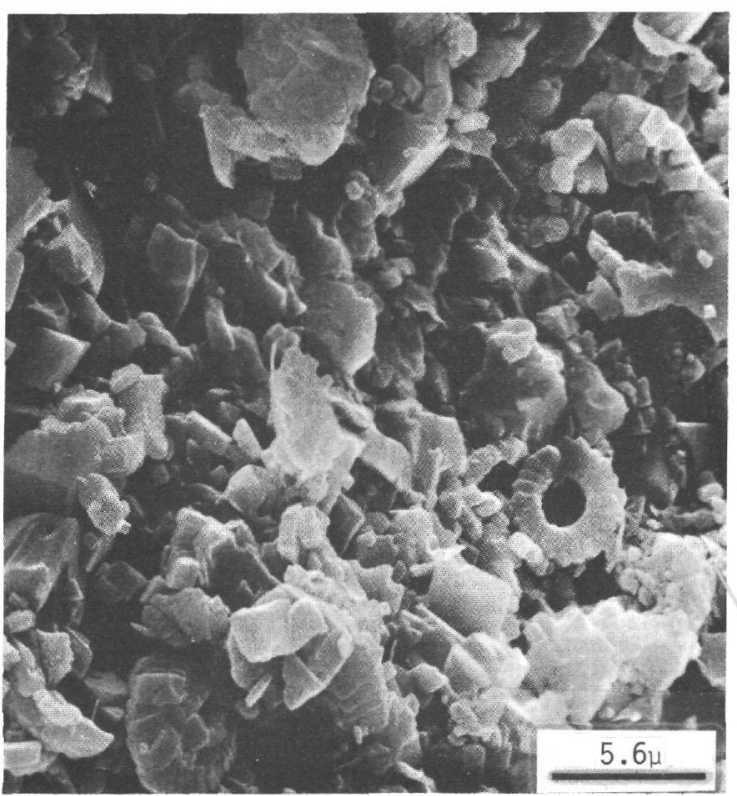

Figure 18. Same sample as Figure 17. Numerous coccoliths show severe etching effects and secondary overgrowths. Fairly well-preserved specimen of the resistant placolith Watznaueria barnasae in the lower left. Note the numerous euhedral rhombs in the cement suggesting dolomite (?).

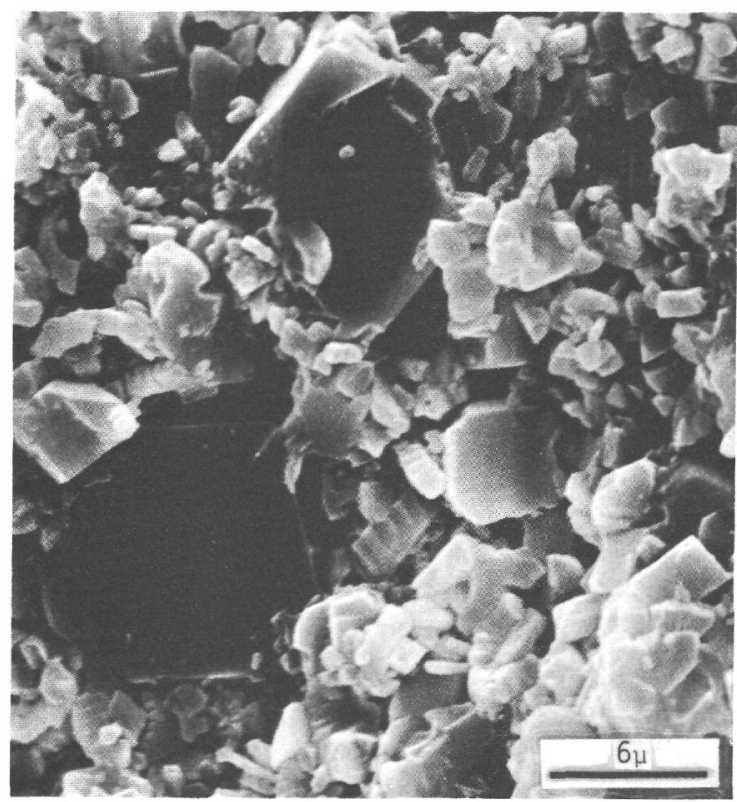

Figure 19. Same sample as Figure 17. The two very euhedral rhombs are strongly suggestive of dolomite. Some fragments of the coccolith Watznaueria are present. 


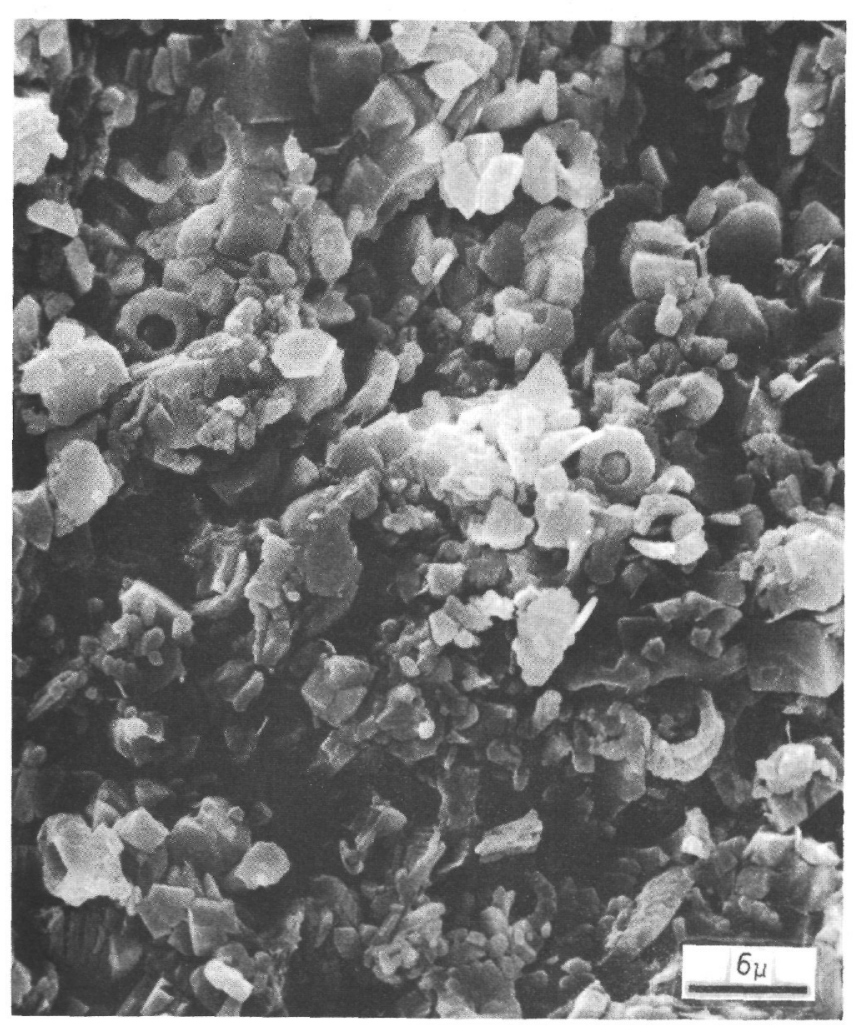

Figure 20. Nannoconid-bearing limestone from the deepest core, 167-94-2. Numerous severely etched and overgrown coccoliths are present-Watznaueria barnasae and the circular Diazomatolithus lehmani. Subhedral to euhedral crystals of calcite and possibly dolomite cement the coccoliths including a slightly etched nannoconid.

Planktonic foraminifera and radiolarians exhibit a good agreement between abundance and state of preservation, but the relationship is less pronounced in nannoplankton. Nannofossils are discrete and recognizable objects even with extensive calcite overgrowth in the limestones. The preservation differences between foraminifera and nannoplankton appear to be mainly resistance to dissolution, foraminifera being less resistant than nannofossils, and size. During compaction the larger and hollow test of planktonic foraminifera are broken and crushed while the tiny nannofossils (10 to 200 times smaller in size) easily fit in the interstices.

\section{Foraminifera}

The change in preservation in the foraminifera assemblages can be summarized in four stages which closely match the four major lithologic units:

Foraminiferal-Nannofossil Ooze ( 0 to 220 meters): In the upper part of the section foraminifera are common to abundant and generally well preserved. Evidence of dissolution is evident from examination of both planktonic and benthonic foraminifera. Hyaline calcareous benthonic foraminifera have glassy lusters down to Core $4(75 \mathrm{~m})$ and thereafter become chalky in appearance. Miliolid species, which are among the high-magnesium, deep-sea species, are present in Cores 1 and 2 as shiny, whole specimens; as chalky, broken specimens in Cores 3 and 4; and as rare fragments in Cores 6 and 7 . No miliolid species were found in any samples below the Neogene oozes (Core 8, $195 \mathrm{~m}$ ). Planktonic foraminifera have etched and chalky textures beginning in Core 3. Nannoplankton exhibit overgrowths in the lower part of the oozes, but evidence of etching was not observed. Foraminifera, more than coccoliths and radiolarians, reflect the early effects of post-depositional diagenesis and at DSDP 167 suffer the greatest destruction of tests.

Foraminiferal-Nannofossil Chalk (220 to 600 meters): No significant change in preservation accompanies the transition from ooze to chalk; the trends begun in the oozes continue. The dissolution of planktonic foraminifera increases in an irregular but progressive fashion, and the absence of thin-walled species becomes noticeable. Fragmentation, which was minor in the ooze, steadily increases downhole in the chalks and reflects the compaction which accompanies the sediment volume loss due to dissolution of foraminifera and increased overburden. An indication of the degree of breakage is provided by the percentage of broken benthonic foraminifera and the ratio of broken uniserial, rectilinear tests to compact, spirally coiled tests ( $\mathrm{R} / \mathrm{S}$ ratio). The rectilinear species, such as Dentalina, Nodosaria, Pleurostomella, and Amphicoryna, are long and narrow and break easily at the junction between chambers. Spiral types, such as Gyroidina, Anomalina, Pullenia, and Cassidulina, are subspherical in shape and more resistant to mechanical breakage. Holes bored in the tests by predators weaken both types of shells, but judging from the examined samples, rectilinear tests are more affected than the spiral types. The $\mathrm{R} / \mathrm{S}$ ratio increases from under 10 to over 50 in the upper part of the chalks and averages around 30 in the lower part of the chalks. The measure becomes less reliable, as indicated by the large variation sample to sample below Core 14, probably because of the preferential fragmentation of rectilinear tests. Below Core 14 there are no unbroken rectilinear or similar-shaped specimens. Once specimens are broken, thereby exposing a greater surface area, they probably become more susceptible to dissolution. However, the process of fragmentation is retarded by cementation and recrystallization which becomes widespread in the lower part of the chalks. This explains the apparent decline in the relative proportion of broken foraminiferal tests.

Nannofossil chalk, chert, and limestone (600 to 827 meters): Between 600 and 827 meters the section is characterized by a variety of carbonate lithologies. Microfossil assemblages undergo major changes in abundance and preservation with the loss of radiolarian assemblages from the section in the upper part of the interval and the loss of foraminifera in the lower part of the interval. Calcareous microfossils show signs of intense loss due to dissolution, fragmentation, replacement, and recrystallization. The rapid increase of benthonic foraminifera to near $50 \%$ of the total assemblages indicates that more than $95 \%$ of the planktonic species have been dissolved (assuming that benthonic species originally represented less than $1 \%$ of the fauna). Calcite overgrowths and partial or complete recrystallization of foraminifera are common and more poorly preserved until foraminifera disappear in Core 55. A few silicified specimens of planktonic species were found in Cores 60 and 61. In the interval between Cores 55 and 59, the last occurrence of foraminifera, there are very rare or 
no rectilinear-shaped species. Only nannoplankton remain relatively in abundance and moderately well preserved through this interval.

Limestone and chert (827 to 1172 meters); In the lowest interval of the section at Site 167 all microfossils are generally poorly preserved and only moderately abundant. Foraminifera are absent except for rare recrystallized or silicified benthonic species observed in thin sections of the limestone.

\section{Nannofossils}

Calcareous nannoplankton of Quaternary to Late Jurassic or Early Cretaceous age are common to abundant throughout this hole.

Core 1 contains well-preserved Late Quaternary assemblages, whereas the assemblages in Core 4 show considerable calcite overgrowth (especially on the discoasters). The onset of calcite overgrowths coincides with onset of dissolution of the forams.

The nannoplankton in the Tertiary part of the section is generally well preserved. Slight etching and some secondary calcite overgrowth was observed in most samples. In contrast, the Early Cretaceous assemblages show strong secondary calcite overgrowth in most samples. The intervals of strong nannofossil overgrowth coincide with intervals of major destruction of foraminiferal assemblages.

Secondary calcite overgrowth and recrystallization of calcareous nannoplankton are species selective. Discoasters are more strongly affected than heliolithids. Among the placoliths species with imbricate elements are the most resistant group, whereas placoliths with nonoverlapping elements are more readily affected by overgrowths. Pontosphaerids and related forms composed of narrow laths are easily destroyed by recrystallization. Etching and overgrowth can be observed in the same sample. The small coccolith elements are dissolved and furnish calcium carbonate which is deposited on other nannofossils with larger elements. Overgrown discoasters develop crystal faces. Ornamentation such as a central knob, ridges, and knobs on the rays, as well as bifurcations at the ray tip disappear gradually. This gradual removal of calcite from smaller forms leads to increased fragmentation of smaller coccoliths. In a section with increasing recrystallization we expect an increase in the relative abundance of discoasters and placoliths with imbricate elements and a decrease in more delicate species like small, nonimbricate placoliths, pontosphaerids, etc.

The soft oozes in the top three cores contain very well preserved nannofossils which lack solution effects or signs of overgrowth. In the Upper Miocene (Core 4) discoasters show some secondary calcite deposits on their arms, and some of the coccoliths show irregular outlines. Middle Miocene to Upper Oligocene discoasters from Cores 5 through 16 are strongly overgrown with secondary calcite. Placoliths with nonimbricate elements also show irregular secondary growth of some of the elements, whereas coccoliths with imbricate elements are almost unaffected. The lower Oligocene assemblages from Cores 17 through 24 show more overgrowth. Discoasters have thick arms and most placoliths show irregular growth of some of the elements. In the Middle and Upper Eocene (Cores 25 through 36) placoliths with imbricate elements (Coccolithus eopelagicus) also show secondary growth. The relative amount of nannofossil fragments increases considerably. In the Paleocene (Cores 39 through 40) practically all the coccoliths show signs of overgrowth and etching.

In the Maastrichtian (Cores 41 through 48) we find many specimens with dissolved central structures. Overgrowths are found on many specimens and there is considerable fragmentation. Coccoliths from the lower Maastrichtian (Cores 44 through 48) seem slightly better preserved than the ones from the Middle Maastrichtian. They are only slightly overgrown, and many specimens have their central structures preserved. Preservation rapidly deteriorates in the lower Campanian. Coniacian to Turonian (Cores 58 through 61) assemblages are strongly overgrown and there is an increase in the relative abundance of resistant forms with imbricate elements (Watznaueria). Fragmentation is also much greater, and from the Cenomanian down probably more than half of the assemblages are broken. In the Lower Cretaceous (Cores 62 through 94) robust forms are relatively enriched. As in Cenozoic assemblages, species with fairly large and strongly imbricate elements are most resistant to diagenetic changes, whereas species constructed of laths or having delicate central structures are destroyed. The following genera and species are dominant in the fairly strongly recrystallized limestones of Albian and Berriasian age and are thus resistant to diagenetic processes: Watznaueria, Tubodiscus, Cyclagelosphaera, Rucinolithus, Cruciellipsis, Cretarhabdus, Tetralithus, Parahabdolithus embergeri, and Nannoconus. Other species with more delicate structures occur in reduced numbers like Eiffellithus turriseiffeli (Albian), Chiastozygus litterarius (Aptian-Albian), Calcicalathina oblongata (Hauterivian, one specimen observed), Lithraphadites bollii, a marker for the Upper Hauterivian to Lower Barremian, and Diadorhombus rectus (Upper Valanginian) are completely missing.

\section{Radiolarians}

Radiolaria were moderately well preserved in the Cenozoic section down to the Middle Eocene. The chert encountered in Core 33 marks the point at which the radiolarian fauna becomes sparse and poorly preserved. From Core 37 (containing the Middle Eocene Thyrsocyrtis triacantha Zone) down to Core 60 , in the lower part of the Upper Cretaceous, the sediments contain no radiolarians. From Core 60 to the basement, Radiolaria are generally sparse; however, they may be abundant in layers that are a few centimeters thick and are commonly found associated with small chert nodules. This part of the section is unzoned with respect to radiolarians, but it contains many forms that are generally recognized as Cretaceous in age.

When found in the lower part of the section, Radiolaria are usually recrystallized and filled with cryptocrystalline silica. Only in Core 78 are the poorly preserved fragments of radiolarians replaced by pyrite. Although recrystallization and replacement have obscured the internal structure of most specimens, surface ornamentation may be well preserved (particularly for specimens from Cores 60, 61, 87 , and 88 ). 


\section{Details of Radiolarian Preservation Change in Representative Cores}

Section 167-5-3: Radiolaria are common and moderately well preserved. The absence of diatoms, the ragged appearance of spongy and delicate forms, and the relative abundance of the more resistant forms indicate that some solution has taken place. However, this may well have been contemporaneous with deposition.

Sections 167-15-3;-5: Radiolaria are common and moderately well preserved. The presence of diatoms and more complete delicate specimens indicate the preservation is slightly better here than in Core 167-5. Again, all solution may have taken place at the sea floor and the difference in preservation may be due solely to the difference in sediment accumulation rate. Pyrite coatings are found on some of the radiolarian tests.

Sample 167-23-CC: Radiolaria are common and moderately well preserved. Diatoms are abundant and the preservation of silica is generally somewhat better than in the above samples. Pyrite coatings are found on some of the specimens, but are not as common as in Core 167-15.

Sample 167-35-CC: Radiolaria are few in number and poorly preserved. Tests generally have a dirty, clay coating, which may be caused by the solution and reprecipitation of opaline silica in the sediment.

Numerous clay aggregates are present that do not break up under strong acid $(\mathrm{HCl})$ and ultrasonic treatment. However, they do break up when treated with a strong base $(\mathrm{NaOH})$. This behavior indicates that amorphous silica is the cement for the aggregates. The sparse radiolarian assemblage suggests that the opaline tests have served as a source for this cement.

The drilling process has mixed better preserved, Upper Eocene radiolarians into this catcher sample of Middle Eocene age.

Sample 167-39-CC: Abundant foraminifera replaced by chalcedonic quartz are present.

Sample 167-41-CC: Aggregates of clay and chalcedonic quartz predominate the acid-treated coarse fraction of this sample. A few silicified forams and rare chalcedonic casts of radiolarians are also present.

Section 167-49-1: Aggregates of clay and chalcedonic quartz compose the acid-treated coarse fraction.

Sample 167-61-2, 104-106 cm: Radiolaria are abundant, but all have been completely replaced and filled by chalcedonic quartz. Silicified benthonic and planktonic forams and clay aggregates are also present in the acidtreated sample.

Sample 167-63-CC: Clay aggregates and rare silicified forams are the sole components of the coarse fraction.

Sample 167-71-1: Abundant subspherical chalcedonic grains are present and are probably replaced or casts of Radiolaria. A few recognizable radiolarians are present. Some are filled with a dark, opaque material.

Sample 167-81-CC: No material greater than $63 \mu$ in diameter was recovered from the acid-treated sample.

Sample 167-92-1-CC: Subspherical chalcedonic particles and clay aggregates with low birefringence are common. Radiolaria replaced by chalcedonic quartz are rare and barely recognizable.

\section{DIAGENETIC MODEL FOR THE OOZE TO CHALK TO LIMESTONE TRANSITION}

The downward diagenetic path in the carbonates drilled at Site 167 is from soft, highly porous, uncemented foraminiferal-nannofossil ooze to hard, less porous, calcitecemented nannofossil limestone. This occurs by physical compaction and the transfer of calcite from less stable to more stable skeletal elements via a solution-reprecipitation process. The diagenetic model outlined below (Figure 21) treats the pure carbonate aspect of these modifications and attempts to account for the major observable changes in the sediments from the sediment/water interface to just above the basaltic basement. Any model is of necessity a construction that takes into account such constraints as:

1) Considerations of the density and porosity of the sediments.

2) A mass balance accounting of the amounts and disposition of the components considering the geologic setting of Site 167.

3) Petrographic observations and the state of preservation of the fossils.

4) Consideration of data from similar sections drilled elsewhere.

\section{Density, Porosity, and Mass Balance Considerations}

The GRAPE density data and porosity plot (Figure 22) show that the densities of the sediments range from approximately $1.35 \mathrm{gm} / \mathrm{cc}$ in the uppermost oozes to approximately $2.0 \mathrm{gm} / \mathrm{cc}$ in the deepest limestones. Assuming that the sediments are pure calcite (Zemmels and Cook, this volume) these density values correspond to porosities of approximately 80\% to 40\%, respectively (Moore, 1969, Figure 23). The diagenetic model must therefore account for a porosity reduction of approximately $40 \%$. Three ways of accounting for such a reduction are: (1) addition of calcite cement by precipitation from interstitial waters without significant textural disturbance of the original sediment; (2) mechanical compaction of the sediment without addition of material to the system in the form of cement; and (3) tighter packing of the original textural elements during overburden increase, a reduction of original intrabiotic porosity both by mechanical breakage and dissolution of the fossils, and precipitation of cement in interparticle voids. The third case appears to best fit the facts and is developed below. Petrographically the sediment system is calcite conservative; i.e., there appears to be a trade-off between the amount of fossil calcite dissolved and the amount of cement precipitated. The model also is calcite conservative, i.e., textural changes observed in the sediments are largely accounted for by the transfer of foraminiferal calcite to nannofossil overgrowths and interparticle cement plus the collapse of the originally very porous framework of tests. It also follows then that there is no need to invoke large-scale movement of cement-bearing formation waters into the sedimentary pile atop Magellan Rise. Indeed, the structure of the Magellan Rise and its accumulating sediment cap at Site 167 is such that there is no apparently reasonable geologic mechanism for driving water into and through the sediments. 
SCHEMATIC DIAGENETIC MODEL OF THE OOZE $\rightarrow$ CHALK $\rightarrow$ LIMESTONE TRANSITION

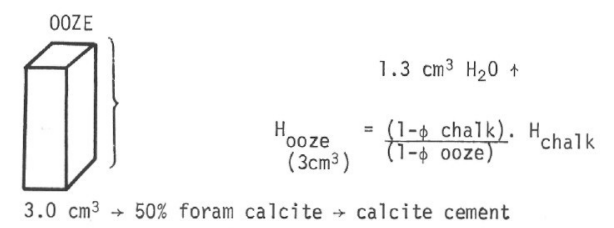

$$
\begin{array}{lcc}
\text { COMPONENT } & \% \text { VOLUME } & \text { WEIGHT } \\
\text { foram calcite } & 10 & 0.82 \mathrm{gms} . \\
\text { nanno calcite } & 10 & 0.82 \mathrm{gms} . \\
\text { water } & 80 & 2.40 \mathrm{gms} . \\
& \text { model } \rho=\frac{4.04}{3.00} \mathrm{gms}^{3} . \\
& & \text { model } \rho=1.35 \\
& \text { model } \phi-80 \%
\end{array}
$$

LITHOLOGIC CHARACTERISTICS

Core 5-- Middle Miocene chalky ooze

$103-112$ meters depth
GRAPE $p=1.27-1.65(=86-63 \%)$

Megascopic:
Foram-nannofossil chalky ooze, whit te, homogeneous, contains rare radiolarians.

diagenetic boundary between true on the

and chalk.
Smear slide:

Abundant foraminifera and nanno-

fosst1s, rare traces of inicriten

recrystalliced tebris.
dem.

Intact tests of we11-preserve

planktonic forams packed in nannofossil
matrix. No obvious cement.
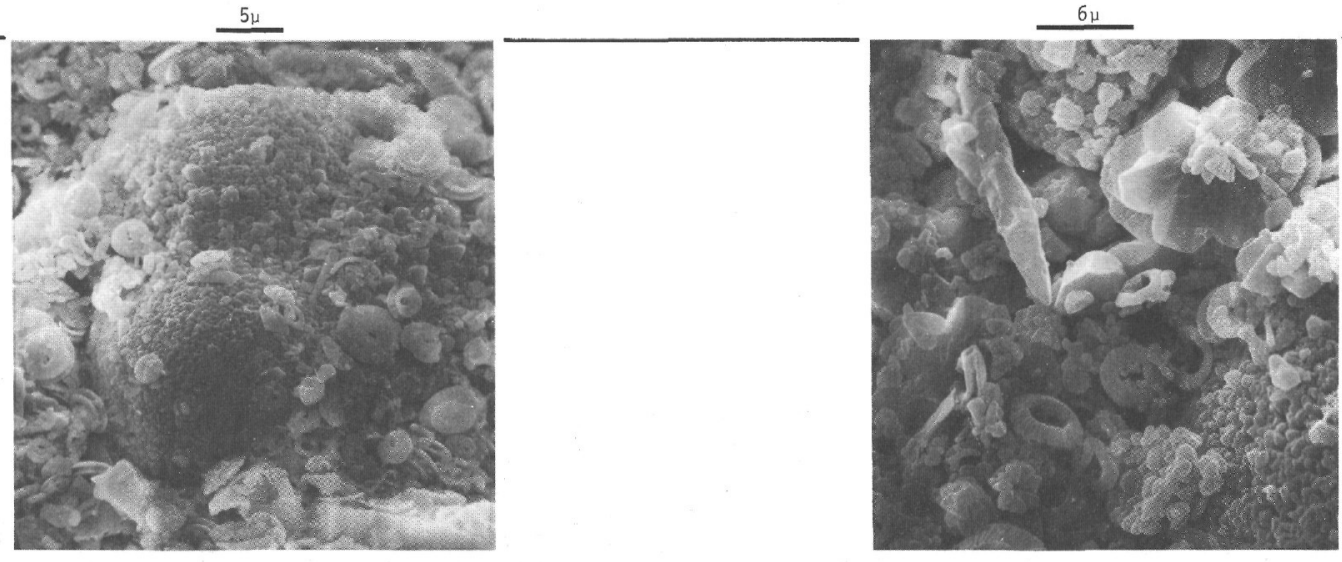

$$
\begin{aligned}
& \text { COMPONENT \% VOLUME WEIGHT } \\
& \begin{array}{lrl}
\text { foram calcite } & \cong 9 & 0.41 \mathrm{gms} \\
\text { nanno calcite } & \cong 18 & 0.82 \mathrm{gms} \\
\text { calcite cement* } & \cong 9 & 0.41 \\
\text { water } & 65 & 1.10 \mathrm{gms} \\
\end{array} \\
& \text { model } \rho=\frac{2.74}{1.70} \mathrm{gms}^{3} \\
& \text { model } \rho=1.60 \\
& \text { model } \phi=65 \%
\end{aligned}
$$

LITHOLOGIC CHARACTERISTICS

Core 11-4-- Late 01 igocene chalk

$$
\begin{aligned}
& 297-306 \text { meters depth } \\
& \text { GRAPE } p=1.64-1.67(64-62 \%)
\end{aligned}
$$

Foram-nannofofssil chalk (some broke down to ooze upon drilling) some pieces ing lithification.

Smear slide:
Common forams, abundant nannofossils, common $" m$.
fossils.

SEM:

tests show strong etching,

framents of tests and abundant "micrite".
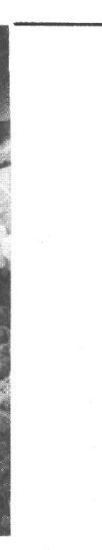

$0.7 \mathrm{~cm}^{3} \mathrm{H}_{2} \mathrm{O}+$

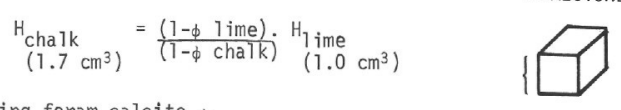

calcite cement + nanno overgrowths $\rightarrow 1.0 \mathrm{~cm}^{3}$

Figure 21. Diagenetic model of the ooze-chalk-limestone transition. 


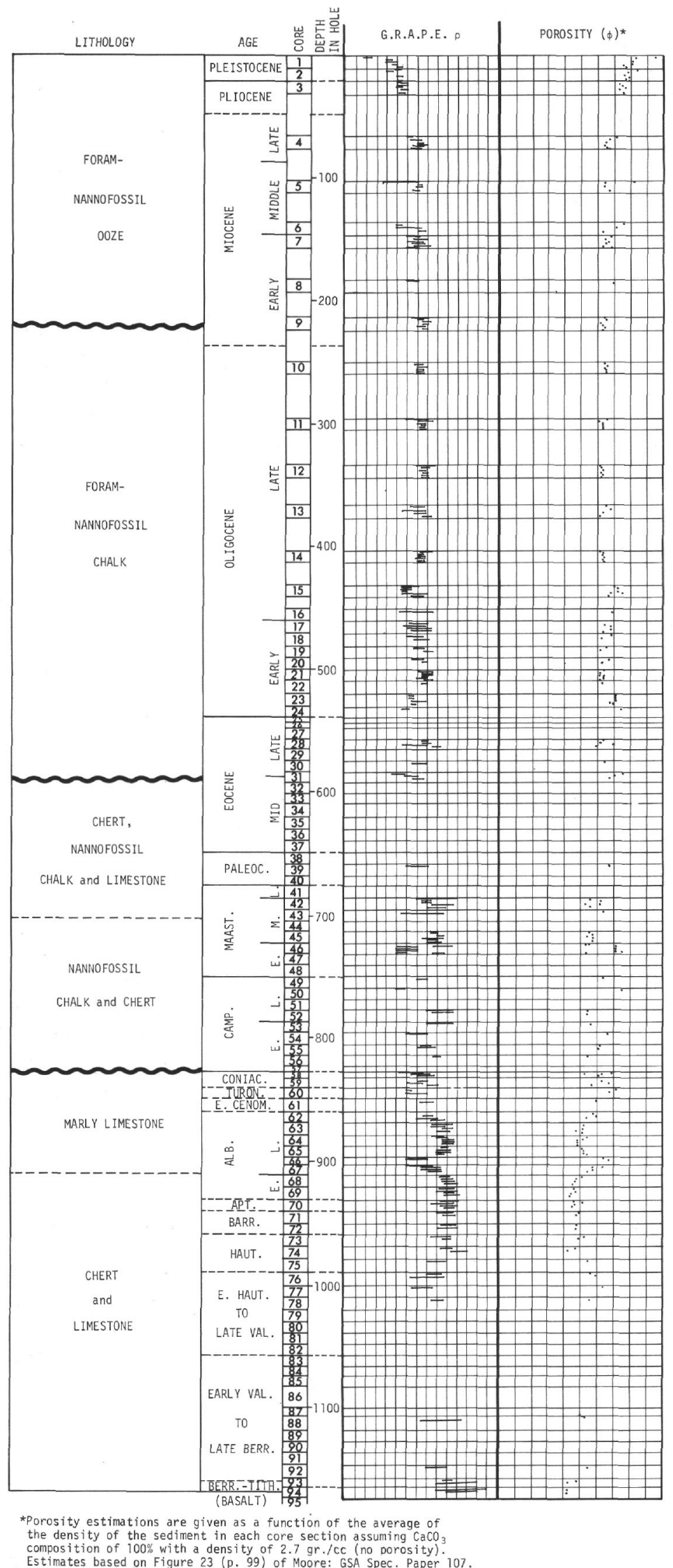

Figure 22. GRAPE density and porosity data, Site 167. 
In order to make an accounting of the components, some volumetric boundary conditions must be established. If no solids are added to the system and water is allowed to leave, then the volume changes during diagenesis can be calculated as if the system was simply compacting as follows:

$$
\text { Let } \mathrm{H}_{\text {ooze }}=\frac{(1-\phi \text { limestone })}{(1-\phi \text { ooze })} \cdot \mathrm{H}_{\text {limestone; }}
$$

where

$$
\begin{aligned}
& \mathrm{H}_{\text {ooze }}=\text { the original thickness of an ooze interval, } \\
& \mathrm{H}_{\text {limestone }}=\text { the thickness of a limestone derived from } \\
& \text { the ooze, } \\
& \left.\phi_{\text {ooze }}=\text { original porosity of ooze (i.e., } 80 \%\right), \\
& \left.\phi_{\text {limestone }}=\text { porosity of limestone (i.e., } 40 \%\right) .
\end{aligned}
$$

Substituting the appropriate values and setting $\mathrm{H}_{\text {limestone }}$ equal to $1 \mathrm{~cm}$ :

$$
\begin{aligned}
& \mathrm{H}_{\text {ooze }}=\frac{(1-0.40)}{(1-0.80)} \cdot 1 \mathrm{~cm} \\
& \mathrm{H}_{\text {ooze }}=3 \mathrm{~cm} .
\end{aligned}
$$

Thus, approximately $3 \mathrm{~cm}^{3}$ of foraminiferal-nannofossil ooze at a density of 1.35 and a porosity of $80 \%$ will reduce to $1 \mathrm{~cm}^{3}$ of nannofossil limestone at a density of approximately 2 and a porosity of $40 \%$ in going from the Quaternary oozes to the Tithonian-Berriasian limestones.

By using a petrographic and textural approach based on SEM photos of pelagic sediments and tests of individual foraminifera, a model of ooze can be developed based on conditions that it:

1) contain equal amounts of foraminifera and nannofossil calcite (smear slides of the upper cores at Site 167 show roughly equal abundances of both fossil types)

2) have a porosity of $80 \%$

3) have a sedimentologically reasonable packing structure.

SEM photographs of foraminifera tests show that the three types of primary intrabiotic porosity (chambers, foramen, and interwall) would make up approximately $80 \%$ of the volume occupied by an individual foraminifera test. Further, a loosely packed aggregate of tests would have primary interparticle porosity. Considering a pure foraminiferal ooze as an aggregate of spheres and considering the interparticle porosity of spherical aggregates ranges from 26 (rhombohedral packing) to 48 (cubic packing) percent, an original interparticle porosity of $45 \%$ is a reasonable one. Thus, $80 \%$ (intrabiotic porosity) of $55 \%$ (sphere volume) equals $44 \%$ and this, plus $45 \%$, equals approximately $90 \%-$ the porosity of a pure foraminiferal ooze. If an equal amount, by volume, of nannofossil calcite (assuming no intrabiotic porosity) is added to the interparticle void space, the resulting ooze is volumetrically: $10 \%$ foram calcite, $10 \%$ nannofossil calcite, and $80 \%$ intrabiotic and interparticle pore space (water filled).
Let these components occupy $3 \mathrm{~cm}^{3}$ so that by weight using 2.72 as density of calcite and 1.00 as density of water:

$$
\begin{aligned}
\text { water }=(0.80 \times 3.0 \times 1.0) & =2.40 \mathrm{~g}, \\
\text { foram calcite }=(0.10 \times 3.0 \times 2.72) & =0.82 \mathrm{~g}, \\
\text { nanno calcite }=(0.10 \times 3.0 \times 2.72) & =0.82 \mathrm{~g} \\
\rho=\frac{4.04}{3.00 \mathrm{~cm}^{3}} & =1.35 \\
\phi & =80 \%
\end{aligned}
$$

This model is a texturally, paleontologically and physically reasonable one for the uppermost oozes at Site 167. The importance of foraminifera in contributing to high initial porosities has been noted by Gealy (1971, p. 1100). This site (Site 64), discussed further below, is quite similar to Site 167 in lithology and diagenetic history. Gealy stated that "Foraminifera tests constitute an important part of the sediment, and there appears to be a correlation between high porosity and high foraminifera content." Cook and Cook (1972, Chapter 23) note that "stratigraphic intervals which contain large amounts of sand-sized radiolarians and foraminifera have higher porosities than beds dominantly of clay sized calcareous nannofossils. The sand-sized biogenous constituents produce a grain-supported texture with both interparticle and intragrain porosity..."

\section{Petrographic Observations and Fossil Preservation}

The major changes from Core 1 to Core 94 involve the mechanical breakdown, dissolution, and eventual wholesale destruction of the framework supporting tests of the foraminifera. This decrease in foraminiferal calcite by dissolution is balanced by a buildup of calcite overgrowths on many nannofossils and the formation of calcite cement. The foraminifera loss amounts to at least $50 \%$ going from ooze to chalk and nearly $100 \%$ from ooze to limestone (Figure 2). The SEM photos (Figures 8, 9, 10) suggest that although many types of nannofossils are etched, the ratio of recognizable nannofossils to recognizable chemical cement is still roughly $1: 1$ in limestones. As shown above, approximately $45 \%$ of the original ooze was intraparticle porosity. Complete dissolution of the tests with reprecipitation of the test calcite as cement and nannofossil overgrowths would result in a maximum porosity reduction in going from ooze to limestone approaching 44\%, very close to the $40 \%$ reduction demanded by this model (Figure 21 ).

The nannofossil limestone components can be tabulated in the same way that the foraminiferal-nannofossil ooze components were above. One $\mathrm{cm}^{3}$ of nannofossil limestone contains by volume:

$30 \%$ nanno calcite, $30 \%$ calcite cement, $40 \%$ interparticle porosity (water filled); 
and by weight:

$$
\begin{array}{ll}
\text { water } & =(0.40 \times 1.0 \times 1.0)=0.40 \mathrm{~g} \\
\text { nanno calcite } & =(0.30 \times 2.72 \times 1.0)=0.82 \mathrm{~g} \\
\text { calcite cement } & =(0.30 \times 2.72 \times 1.0)=\frac{0.82}{2.04} \mathrm{~g}
\end{array}
$$

This model agrees with the textures observed in SEM photos from the deepest limestone cores (Figures 18, 19, 20 ) and has the physical properties of these limestone; i.e., $40 \%$ porosity and a density of 2.0 .

The model, as illustrated, assumes only foraminifera to nannofossil overgrowth and cement calcite transfer. The observations described above on both nannofossils and foraminifera show that some species of nannofossils also dissolve and some foraminifera show overgrowths. In the case of the foraminifera it may be that certain parts of the shell walls are more soluble than other parts due to an original $\mathrm{Mg}$ difference. Therefore, a number of possible unstable $\rightarrow$ stable calcite transfer systems probably exist. These are listed in a suggested rank ordering of importance based on observations of the sediments at Site 167 and a brief literature survey.

$$
\begin{aligned}
& \text { foraminiferal test } \rightarrow \text { nannofossil overgrowths } \\
& \text { foraminiferal test } \rightarrow \text { cement } \\
& \text { nannofossil } \rightarrow \text { nannofossil overgrowth } \\
& \text { nannofossil } \rightarrow \text { cement }
\end{aligned}
$$

An intermediate step along the diagenetic path from ooze to limestone is the chalk stage. Examination of the GRAPE and porosity data of Figure 22 shows that the density of the sediments increases quite rapidly within the upper 50 meters. By the depth of approximately 50 meters, between Cores 3 and 4 , the density has increased from 1.3-1.4 at the surface to approximately 1.6. From Core 4 (75 meters) down to the first cherts at 600 meters, the GRAPE density remains reasonably constant at about 1.6 with porosities of $60 \%$ to $70 \%$. The smear slide summaries (Chapter 5) and the fossil preservation data discussed above show that:

1) Hyaline calcareous benthonic foraminifera have glassy luster down to Core 4; miliolid species present in Cores 1 and 2 as shiny whole specimens are chalky and broken in Cores 3 and 4 and are represented only as rare fragments in Cores 6 and 7, and are missing below Core 8; planktonic species are etched and chalky beginning in Core 3.

2) Fine-grained calcite produced by recrystallization of some original constituents, probably foraminifera, shows up in the smear slides beginning in Core 4 and becoming prominent by Core 9 .

The rapid density increase in the upper 50 meters followed by a long section $(600 \mathrm{~m})$ of relatively constant density strongly suggests that the compaction due to loading is most important in the first few tens of meters and does not radically alter the sediment structure. A similar density-depth relationship was noted at Site 62.1 (Leg 7). As long as foraminifera tests are only surficially attacked by dissolution, the supporting framework of tests remains relatively intact and maintains a high (60\% to $70 \%)$ porosity. The reduction in porosity of approximately $15 \%$ due to loading could be accounted for by a combination of the breaking of some tests plus the closer packing of the many still largely intact planktonic foraminiferal tests and the originally small percentage of easily dissolved benthonic tests. The first appearance of micritic grains in Core 4 and the appearance of nannofossil overgrowths indicate that the chemical transfer of calcite due to the dissolution of tests, from foraminifera to cement and nannofossil overgrowths has begun. Figure 21 is a schematic representation of the ooze-chalk-limestone diagenetic model.

\section{Considerations of Data From Similar Sections Drilled Elsewhere}

Neither time nor space limitations permit a comprehensive review of lithologic, fossil preservation, porosity, and diagenetic data from other DSDP sites. However, certain Pacific sites at which thick sections of relatively pure carbonates were drilled show some similarity to Site 167. Cook and Cook (1972, Chapter 23) note that the Leg 9 porosity values ranged from $94 \%$ to $41 \%$ and that "At most sites there is a definite downhole decrease in porosity which may be due to compaction, incipient cementation, or both." Site 79 is referred to as a good example. There, 414 meters of sediment ranging from Pleistocene foraminiferalradiolarian-calcareous nannofossil oozes (Core 1, 0-9 meters subsurface) to Lower Miocene foraminiferal-calcareousnannofossil chalks (Core 16, 406-413 meters subsurface) were drilled. In Core 1 the porosity was $87 \%$ and in Core $16,45 \%$. For Leg 8 Tracy et al. (1971) report (p. 22) that "The degree of induration of the pelagic oozes at all sites seem to be related to age of the sediments and to depth of burial." Further, detailed plots of data (p. 23) "indicate a decrease in porosity and an increase in stiffness as might be expected from gravitational compaction and partial lithification." On Leg 7 Gealy (1971, Chapter 24, p. 1103-1104) points out that Sites 62,63 , and 64 "penetrated sequences of nannofossil ooze-chalk-limestone as deep as 985 meters and old as Middle Eocene." Gealy further stated concerning these sites "The saturated bulk density of near surface Quaternary nannofossil oozes had a saturated bulk density of about $1.5 \mathrm{gm} / \mathrm{cm}^{3}$ and a porosity of $72 \%$ at all three sites. The porosity decreases irregularly with depth at all three sites, and the rate of decrease appears to be related not only to depth of burial, but to age. For example, the saturated bulk density and porosity of Late Oligocene nannofossil ooze are almost identical at the three sites, as are those of Middle Miocene age, despite different depths of burial:

\begin{tabular}{l|rrr|rrr|rrr}
\cline { 2 - 9 } & \multicolumn{3}{|c|}{ Site 62 } & \multicolumn{3}{c|}{ Site 63 } & \multicolumn{3}{c}{ Site 64 } \\
\hline & $\begin{array}{c}\text { Depth } \\
(\mathrm{m})\end{array}$ & $\rho \mathrm{B}$ & $\phi$ & $\begin{array}{c}\text { Depth } \\
(\mathrm{m})\end{array}$ & $\rho \mathrm{B}$ & $\phi$ & $\begin{array}{l}\text { Depth } \\
(\mathrm{m})\end{array}$ & $\rho \mathrm{B}$ & $\phi$ \\
$\begin{array}{l}\text { Recent } \\
\text { Middle }\end{array}$ & 340 & 1.50 & 72 & 0 & 1.50 & 72 & 0 & 1.50 & 72 \\
$\begin{array}{l}\text { Miocene } \\
\begin{array}{l}\text { Late } \\
\text { Oligocene }\end{array}\end{array}$ & 520 & 1.90 & 49 & 350 & 1.91 & 49 & 560 & 1.85 & 51 \\
\hline
\end{tabular}


At all three sites, important reversals (where porosity decreases with depth and then increases) which appear real and not artifacts are found on both the centimeter and decimeter scale. At Site 62 , the porosity is 54 percent at 215 meters, and 60 percent at 275 meters. At Site 63, the porosity is 60 percent at 65 meters, and 65 percent or less at 120 meters. At Site 64 , the porosity is 50 percent at 570 meters, and 54 percent at 615 meters."

These data can be interpreted as supporting the contention that depth of burial beyond some tens of meters has little influence on the porosity of the sediment.

Detailed porosity data from Gealy for these sites indicates that the porosity/depth/age relationships are similar to those at Site 167. At Site 62.1 the Quaternary foram-nannofossil ooze from Core 1 , Section 2 at 8.25 meters subdepth had a porosity of $76.8 \%$; Core 35 , Section 5, a Middle Miocene nannofossil chalk cored at 333.75 meters, had a porosity of $58.3 \%$. Minor reversals in porosity over intervals of a few meters do occur but there is a steady decrease in porosity with depth and age. The porosity does, however, drop below $70 \%$ by 57.75 meters subbottom depth and does not reach that high a value again. This rapid porosity decrease followed by a long interval with porosities of from roughly $55 \%$ to $65 \%$ is similar to the situation at Site 167. Site 64 is similar to Site 62; Quaternary foram-nannofossil ooze at a subbottom depth of 3.75 meters had a porosity of $71.9 \%$ and nannofossil chalk and limestone of early Oligocene age had a porosity of $45.2 \%$ at a depth of 850 meters. The lithology of the section at Site 64 indicates that intervals of chalk alternate with chalk ooze in the middle part of the section $(400-750 \mathrm{~m})$ and that in the deeper parts of the section friable chalk and harder limestone alternate.

The model so far presented is extremely simplistic in that the only variables considered important are: (1) an initial composition that includes an easily dissolved calcite phase that serves as a cement source and a more stable calcite that serves as a cement substrate, (2) time, and (3) to a lesser extent, depth of burial. It does not fit all the data available. For example, the model, without consideration of further variables, demands that oozes not occur below chalks and limestones not occur above chalks. The alternation of lithologic types at Site 64 shows that such cementation reversals do occur. Further, well-preserved foraminiferal faunas were found throughout the postMiocene section at that site. At Site 167 density reversals occur in the deepest parts of the section. One could argue that an ooze below a chalk sequence is possible if the ooze contained little mobile calcite to start with, perhaps due to an original lack of foraminiferal calcite.

In order to design a model capable of predicting the state of lithification of any potential core it would be necessary to consider at least all of the following:

1) Ratio of foraminifera to nannofossils to other carbonate secreting organisms produced per unit time in the sea-water column and the differential rates of solution of these components as they fell through the sea-water column. These rates affect the ratio of unstable to stable carbonate in the surficial sediments.

2) Variations in the sedimentation rate as the rate influenced the residence time of the surviving fossils at and near the water-sediment boundary. The degree of preservation of the potential faunal assemblage will reflect the length of time spent at this diagenetically important boundary where bioturbation, predation, and solution are rapid.

3) Original depth of deposition of the sediment.

4) Subsequent history of vertical motion of the region.

5) Thermal history at the site in terms of both regional heat flow and local intrusions.

6) Effects of noncarbonate sediments and silicate diagenesis.

The geochemical implications of the model have not been treated in this chapter. The paths of the cations such as $\mathrm{Mg}$ and $\mathrm{Sr}$ need to be traced and the exchange possibilities of the oxygen-carbon isotopes are limited by the model. Further, the chemical mechanisms and thermodynamics of a system that promotes dissolution of the foraminifera calcite and stimulates precipitation of calcite as overgrowths on nannofossils and as discrete interparticle cement while water is being expressed need to be evaluated.

\section{ACKNOWLEDGMENTS}

This study was supported in part by NSF grant GA 31622 and The Marathon Oil Company. The authors wish to thank Mrs. Betty Murray of the Deep Sea Drilling Project staff and Mr. Michael A. Arthur, both of the University of California, Riverside, for assistance in preparation of the manuscript and illustrations and Mrs. Eva Topfl, Case Western Reserve University, for assistance in preparation of the foraminiferal data.

\section{REFERENCES}

Berger, W. H., 1971. Sedimentation of planktonic foraminifera: Mar. Geol., V. 11, p. 325.

Bukry, D., Douglas, R. G., Kling, S.A., and Krasheninnikov, V. V., 1971. Planktonic microfossil biostratigraphy of the northwestern Pacific area: Initial Reports of the Deep Sea Drilling Project, Volume VI, Washington (U. S. Government Printing Office), p. 1253-1300.

Cook, F. M. and Cook, H. E., 1972. Physical properties synthesis: Initial Reports of the Deep Sea Drilling Project, Volume IX. Washington (U. S. Government Printing Office), p. 945-946.

Gealy, E. L., 1971, Saturated bulk density, grain density and porosity of sediment cores from the western equatorial Pacific: Leg 7, Glomar Challenger: Initial Reports of the Deep Sea Drilling Project, Volume VII. Washington (U.S. Government Printing Office), p. 1081-1104.

Gealy, E. L., Winterer, E. L., and Moberly, R., 1971. Methods, conventions, and general observations: Initial Reports of the Deep Sea Drilling Project. Volume VII. Washington (U. S. Government Printing Office), p. 9-26.

Kling, S. A., 1971. Radiolaria, Leg 6 of the Deep Sea Drilling Project: Initial Reports of the Deep Sea Drilling Project, Volume VI. Washington (U. S. Government Printing Office), p. 1069-1118. 
Moore, D. G., 1969. Reflection profiling studies of the California continental borderland: Structure and Quaternary turbidite basins. Geol. Soc. Am. Spec. Paper 107.

Peterson, M. N. A., 1966. Calcite: rates of dissolution in a vertical profile in the central Pacific: Science, U. 154, p. 1542.

Roth, P. H., and Thierstein, H., 1972. Calcareous nannoplankton: Leg 14 of the Deep Sea Drilling Project:
Initial Reports of the Deep Sea Drilling Project, Volume XIV. Washington (U. S. Government Printing Office), p. 421 .

Tracey, J. I., Jr., et al., 1971. Initial Reports of the Deep Sea Drilling Project, Volume VIII. Washington (U. S. Government Printing Office), p. 1037.

Winterer, E. L., et al., 1971. Initial Reports of the Deep Sea Drilling Project, Volume VII. Washington (U.S. Government Printing Office), p. 1757. 